\title{
Gold Stabilized by Nanostructured Ceria Supports: Nature of the Active Sites and Catalytic Performance
}

\author{
Yejun Guan · D. A. J. Michel Ligthart • \\ Özlem Pirgon-Galin · Johannis A. Z. Pieterse • \\ Rutger A. van Santen · Emiel J. M. Hensen
}

Published online: 8 February 2011

(c) The Author(s) 2011. This article is published with open access at Springerlink.com

\begin{abstract}
The interaction of gold atoms with $\mathrm{CeO}_{2}$ nanocrystals having rod and cube shapes has been examined by cyanide leaching, TEM, TPR, CO IR and X-ray absorption spectroscopy. After deposition-precipitation and calcination of gold, these surfaces contain gold nanoparticles in the range $2-6 \mathrm{~nm}$. For the ceria nanorods, a substantial amount of gold is present as cations that replace Ce ions in the surface as follows from their first and second coordination shells of oxygen and cerium by EXAFS analysis. These cations are stable against cyanide leaching in contrast to gold nanoparticles. Upon reduction the isolated Au atoms form finely dispersed metal clusters with a high activity in $\mathrm{CO}$ oxidation, the WGS reaction and 1,3-butadiene hydrogenation. By analogy with the very low activity of reduced gold nanoparticles on ceria nanocubes exposing the $\{100\}$ surface plane, it is inferred that the gold nanoparticles on the ceria nanorod surface also have a low activity in such reactions. Although the finely dispersed Au clusters are thermally stable up to quite high temperature in line with earlier findings (Y. Guan and E. J. M. Hensen, Phys Chem Chem Phys 11:9578, 2009), the presence of gold nanoparticles results in their more facile agglomeration, especially in the presence of water (e.g., WGS conditions). For liquid phase alcohol oxidation, metallic gold nanoparticles are the active sites. In the absence of a base, the $\mathrm{O}-\mathrm{H}$ bond cleavage appears to be rate
\end{abstract}

Y. Guan · D. A. J. M. Ligthart · R. A. van Santen

E. J. M. Hensen $(\bowtie)$

Schuit Institute of Catalysis, Eindhoven University

of Technology, P.O. Box 513, 5600 MB Eindhoven,

The Netherlands

e-mail: e.j.m.hensen@tue.nl

Ö. Pirgon-Galin · J. A. Z. Pieterse

Energie Centrum Nederland, P.O. Box 1, 1755 ZG Petten,

The Netherlands limiting, while this shifts to $\mathrm{C}-\mathrm{H}$ bond activation after addition of $\mathrm{NaOH}$. In the latter case, the gold nanoparticles on the surface of ceria nanocubes are much more active than those on the surface of nanorod ceria.

Keywords Gold · Ceria - Particle size - Active sites . Reduction · Oxidation

\section{Introduction}

Gold nanoparticles stabilized by reducible transition metal oxides can efficiently catalyze many interesting reactions [1-3], the most notable one being the low temperature oxidation of $\mathrm{CO}$ as first described by Haruta et al. [4]. Of determining importance appear to be the size of the metal nanoparticles or clusters, the ability of the support to provide oxygen atoms during catalytic reactions and the influence of the oxidation state of the gold atoms in close proximity to the surface. Among the reducible oxides, ceria $\left(\mathrm{CeO}_{2}\right)$ is one of the most efficient supports, because of its capability to store oxygen and become reduced [5, 6]. Ceria-supported gold has been shown to catalyze important reactions such as $\mathrm{CO}$ oxidation [7, 8], alcohol oxidation [9], hydrogenation [10, 11] and the water-gas shift (WGS) reaction [12].

The active site in $\mathrm{Au} / \mathrm{CeO}_{2}$ catalysts will not be the same for all these reactions. $\mathrm{Au}^{3+}, \mathrm{Au}^{+}$and $\mathrm{Au}^{0}$ are known to exist in different proportions in ceria-supported $\mathrm{Au}$ catalysts. The exact surface composition will depend on the method of preparation and pretreatment and the metal loading. For instance, Gates and co-workers considered that there is a strong possibility that there are multiple reaction channels for catalysis of $\mathrm{CO}$ oxidation by supported gold, involving gold in different oxidation states [3]. For the WGS reaction, isolated gold cations have been 
claimed as the active sites [12], although more recently there appears to be consensus that metallic gold cluster are the active sites $[13,14]$. A similar debate is apparent about the active sites in alkene hydrogenation [11, 15-17].

In line with the importance of the interactions between gold and the support, it has been found that nanoscale forms of ceria contribute to the high activity of small gold particles [18-24]. Several authors [25-28] have used nanostructured ceria that expose certain planes to investigate the influence of the nature of the ceria surface on the nature and activity of gold species. By judicious choice of the hydrothermal treatment conditions of hydrolyzed cerium(III) salts, singlecrystalline nanopolyhedra, nanorods and nanocubes were obtained $[29,30]$. The results of such studies confirm the strong effect of the crystal plane of ceria on the activity of gold for the WGS and CO oxidation reactions. Gold particles on $\{110\}$ planes as present on nanorods are more active than those stabilized by $\{100\}$ planes of nanocubes.

The surface of ceria has been very extensively studied by experimental and theoretical methods. In relation to gold catalysis, it has been argued that surface defects like cerium and oxygen vacancies play a role in the nucleation and stabilization of gold nanoparticles [31-36]. Another relevant issue is the stabilization of cationic gold in ceria, either at the surface or as a solid solution. Several authors have discussed the substitution of $\mathrm{Ce}^{3+} / \mathrm{Ce}^{4+}$ by $\mathrm{Au}^{3+}[20,37-40]$. Recently, EXAFS structure analysis showed that the isolated $\mathrm{Au}$ cations in leached $\mathrm{Au} / \mathrm{CeO}_{2}$ are surrounded by oxygen and cerium, respectively, in the first and second coordination shell in agreement with Au substitution for Ce [11]. Thermodynamically, the adsorption of $\mathrm{Au}$ on $\mathrm{O}$ vacancies is favored over adsorption on Ce vacancies [33, 40].

In this work, we use the approach of ceria exposing certain crystal planes (nanorods and nanocubes) to stabilize gold nanoparticles to investigate in detail the nature of the gold phase before and after leaching with cyanide. In situ X-ray absorption spectroscopy, transmission electron microscopy, temperature programmed reduction and CO IR spectroscopy are used to study the surface of the $\mathrm{Au} / \mathrm{CeO}_{2}$ catalysts. By comparing the activity of these catalysts in a wide range of reactions (CO oxidation, alcohol oxidation, butadiene hydrogenation, WGS), we aim to provide further insight into the active site requirements for the various types of reactions.

\section{Experimental}

\subsection{Synthesis of Materials}

\subsubsection{Nanostructured $\mathrm{CeO}_{2}$}

$\mathrm{CeO}_{2}$ support materials with controlled crystal shapes were prepared according to literature procedures [30, 41].
Typically, $40 \mathrm{~mL}$ of $0.5 \mathrm{M} \mathrm{Ce}\left(\mathrm{NO}_{3}\right)_{3}$ aqueous solution and $60 \mathrm{~mL}$ of $10 \mathrm{M} \mathrm{NaOH}$ solution were added to a $125 \mathrm{~mL}$ Teflon-lined stainless-steel autoclave and stirred for $30 \mathrm{~min}$ at room temperature. The sealed autoclave was then transferred to an oven at $373 \mathrm{~K}$ (nanorods) or $453 \mathrm{~K}$ (nanocubes) and kept at this temperature for $24 \mathrm{~h}$. Subsequently, the precipitate was filtered and thoroughly washed by distilled water several times until the $\mathrm{pH}$ of the filtrate was 7 . Finally, the precipitate was dried at $383 \mathrm{~K}$ overnight and calcined at $773 \mathrm{~K}$ in air for $4 \mathrm{~h}$. The rod- and cube-shaped crystals are denoted by $\mathrm{CeO}_{2}$ (rod) and $\mathrm{CeO}_{2}$ (cube), respectively. The powder X-ray diffraction (XRD, Bruker D4, Cu K $\alpha$ ) show the cubic fluorite structure of $\mathrm{CeO}_{2}$ (space group: $F m 3 m$ ) for these two materials.

\subsection{2 $\mathrm{Au} / \mathrm{CeO}_{2}$ Catalysts}

Gold catalysts were prepared by deposition-precipitation of gold on the ceria supports [11, 12]. In a typical synthesis, the desired amount of $\mathrm{HAuCl}_{4}$ and urea were dissolved in $100 \mathrm{~mL}$ of distilled water. After addition of $2 \mathrm{~g}$ of ceria, the solution was refluxed at $363 \mathrm{~K}$ for $2 \mathrm{~h}$. Subsequently, the solid was filtered, dried at $383 \mathrm{~K}$ and optionally calcined at $673 \mathrm{~K}$. The target gold loadings were 1, 2 and $6 \mathrm{wt} \%$. A portion of the catalysts was treated with a cyanide-containing solution. An amount of the catalyst was suspended in a $2 \mathrm{wt} \% \mathrm{NaCN}$ solution (CN/Au molar ratio $=2$ ) at a $\mathrm{pH}$ of 12 by addition of $\mathrm{NaOH}$ and stirred overnight under aeration. After this leaching treatment, the resulting suspension was filtered, dried at $383 \mathrm{~K}$ overnight and calcined at $673 \mathrm{~K}$ for $4 \mathrm{~h}$ in air. The gold catalysts are denoted by $\mathrm{Au} / \mathrm{CeO}_{2}$ (crystal shape)-CN with the optional postfix to indicate the leaching treatment.

\subsection{Characterization of Materials}

\subsubsection{Elemental Analysis}

The gold loading was determined by inductively coupled plasma atomic emission spectroscopy (ICP-OES) analyses performed on a Goffin Meyvis SpectroCirus ${ }^{\text {ccd }}$ apparatus. The samples were dissolved in a $3: 1 \mathrm{HCl} / \mathrm{HNO}_{3}$ solution.

\subsubsection{XRD}

Powder XRD diffractograms were recorded on Bruker D4 Endeavour $\left(\mathrm{Cu} \mathrm{K} \alpha\right.$, scan between 10 and $80^{\circ}, 0.02^{\circ}$ per step and $2.5 \mathrm{~s}$ per step).

\subsubsection{Textural Properties}

The BET surface area was measured by nitrogen adsorption at $77 \mathrm{~K}$ on a Micromeretics Tristar 3000 analyzer after drying the materials at $423 \mathrm{~K}$. 


\subsubsection{Transmission Electron Microscopy}

Electron micrographs of the support materials and catalysts were taken with a FEI Tecnai 20 electron microscope at an acceleration voltage of $200 \mathrm{kV}$ with a $\mathrm{LaB}_{6}$ filament. Typically, a small amount of sample was ground and suspended in ethanol, sonicated and dispersed over a $\mathrm{Cu}$ grid with carbon film.

\subsubsection{Temperature-Programmed Reduction (TPR)}

TPR experiments were carried out in a flow apparatus equipped with a fixed-bed reactor, a computer-controlled oven and a thermal conductivity detector. Typically, an amount of catalyst was contained between two quartz wool plugs in a quartz reactor. Prior to TPR, the catalyst was oxidized by exposure to a flowing mixture of 4 vol\% $\mathrm{O}_{2}$ in He under heating to $723 \mathrm{~K}$ at a rate of $10 \mathrm{~K} / \mathrm{min}$. After the sample was cooled to room temperature in flowing nitrogen, the sample was reduced in 4 vol\% $\mathrm{H}_{2}$ in $\mathrm{N}_{2}$ at a flow rate of $8 \mathrm{~mL} / \mathrm{min}$, whilst heating from room temperature up to $1073 \mathrm{~K}$ at a ramp rate of $10 \mathrm{~K} / \mathrm{min}$. The $\mathrm{H}_{2}$ signal was calibrated using a $\mathrm{CuO} / \mathrm{SiO}_{2}$ reference catalyst.

\subsubsection{Infrared Spectroscopy of Adsorbed CO}

Infrared spectra were recorded at room temperature on a Bruker IFS-113v Fourier transform IR spectrometer with a DTGS detector at a resolution of $4 \mathrm{~cm}^{-1}$. Typically, a wafer was prepared with a density of $\sim 10 \mathrm{mg} / \mathrm{cm}^{2}$ and placed in a controlled atmosphere cell. The sample was pretreated in oxygen or hydrogen at the desired temperature for $1 \mathrm{~h}$. Subsequently, the cell was evacuated to a pressure lower than $10^{-6}$ mbar and the sample was cooled to $80 \mathrm{~K}$. An initial infrared spectrum was recorded that served as the background for further spectra. Small doses of $\mathrm{CO}(\sim 0.4 \mu \mathrm{mol})$ were introduced into the cell followed by recording an IR spectrum until saturation of the bands in the carbonyl stretching region. FTIR spectra of adsorbed $\mathrm{CO}$ were then recorded intermittent to the following treatment scheme: (i) reduction by $\mathrm{H}_{2}$ at $393 \mathrm{~K}$, (ii) reoxidation at $313 \mathrm{~K}$, (iii) reduction at $773 \mathrm{~K}$ and (iv) reoxidation at $313 \mathrm{~K}$. Each step was followed by extensive evacuation and cooling to $80 \mathrm{~K}$.

\subsubsection{X-Ray Absorption Spectroscopy (XAS)}

X-ray absorption measurements were carried out at the Dutch-Belgian Beamline (Dubble) at the ESRF (France). Data were collected at the $\mathrm{Au} \mathrm{L}_{\mathrm{III}}$ edge in fluorescence mode with a 9-channel solid-state detector. To decrease the strong fluorescent radiation caused by cerium, an aluminum foil (thickness $60 \mu \mathrm{m}$ ) was placed in front of the fluorescence detector. Energy selection was done by a double crystal Si(111) monochromator. Background removal was carried out by standard procedures with the Viper software. EXAFS analysis was then performed with EXCURVE931 on $k^{3}$-weighted unfiltered raw data using the curved wave theory. Phase shifts were derived from $\mathrm{ab}$ initio calculations using Hedin-Lundqvist exchange potentials and Von Barth ground states. Energy calibration was carried out with a gold foil. The amplitude reduction factor $S_{0}^{2}$ associated with central atom shake-up and shakeoff effects was set at 0.88 by calibration of the first- and second-shell $\mathrm{Au}-\mathrm{Au}$ coordination numbers to 12 and 4, respectively, for $k^{3}$-weighted EXAFS fits of the $\mathrm{Au}$ foil. The whiteline of the XANES part of the absorption spectrum was fitted by linear combinations of reference catalysts by a least-squares method.

Spectra at the $\mathrm{Au} \mathrm{L}_{\mathrm{III}}$ edge were recorded in a stainlesssteel controlled atmosphere cell. The cell was heated with two firerods controlled by a temperature controller via a thermocouple placed close to the catalyst sample. Typically, an amount of $100 \mathrm{mg}$ of sample was pressed in a stainless steel holder and placed in the cell. High-purity carbon foils with a thickness of $150 \mu \mathrm{m}$ were used as windows. High-purity gases $\left(\mathrm{He}, 5 \mathrm{vol} \% \mathrm{H}_{2}\right.$ in $\mathrm{He}$ or 20 vol $\% \mathrm{O}_{2}$ in $\mathrm{He}$ ) were delivered by Bronkhorst thermal mass flow controllers. The total gas flow was kept at $20 \mathrm{~mL} / \mathrm{min}$. The catalyst sample was heated in He to $393 \mathrm{~K}$ at a rate of $10 \mathrm{~K} / \mathrm{min}$. EXAFS spectra were recorded after cooling to room temperature. For the high-loading catalyst three consecutive scans were measured, while for the low-loading catalysts six scans were averaged. For in situ WGS experiments the feed consisted of a flow of $5.8 \mathrm{vol} \% \mathrm{CO}$ and $11.6 \mathrm{vol} \% \mathrm{H}_{2} \mathrm{O}$ in $\mathrm{He}$ at a total flow rate of $50 \mathrm{~mL} / \mathrm{min}$. The CO conversion was determined by a Agilent MicroGC system equipped with a Porapak $\mathrm{Q}$ column with a thermal conductivity detector.

\subsection{Catalytic Activity Measurements}

The catalytic activity in the oxidation of carbon monoxide and the hydrogenation of 1,3-butadiene was evaluated in a parallel ten-flow microreactor system. The effluent products $\left(\mathrm{CO}, \mathrm{CO}_{2}\right.$ and $\mathrm{O}_{2}$ for $\mathrm{CO}$ oxidation and 1,3-butadiene, butenes and butanes for 1,3-butadiene hydrogenation) were analyzed by an Interscience CompactGC online gas chromatograph equipped with Porapak Q (TCD), Molecular sieve $5 \mathrm{~A}$ (TCD) and a PLOT $\mathrm{KCl} / \mathrm{Al}_{2} \mathrm{O}_{3}$ columns (FID). For $\mathrm{CO}$ oxidation, the feed mixture contained 1 vol\% $\mathrm{CO}$ and $1 \mathrm{vol} \% \mathrm{O}_{2}$ in $\mathrm{He}$ at a total flowrate of $100 \mathrm{~mL} / \mathrm{min}$. An amount of $15 \mathrm{mg}$ of catalyst was diluted with $250 \mathrm{mg}$ of $\mathrm{SiC}$ of the same sieve fraction and contained between two quartz wool plugs in a quartz reactor with an internal diameter of $4 \mathrm{~nm}$. CO conversion was determined in the 
temperature range from 293 to $373 \mathrm{~K}$. Hydrogenation of 1,3-butadiene was carried out at $383 \mathrm{~K}$ in a mixture of 2 vol\% 1,3-butadiene in $\mathrm{H}_{2}$ at a total flow rate of $20 \mathrm{~mL} / \mathrm{min}$. Prior to reaction, the catalysts were pretreated at $393 \mathrm{~K}$ in a flow of $10 \mathrm{vol} \% \mathrm{H}_{2}$ in $\mathrm{He}$.

The water gas shift (WGS) reaction was carried out in a quartz reactor with an internal diameter of $4 \mathrm{~mm}$. Typically, an amount of $50 \mathrm{mg}$ catalyst was used. The feed flow was $40 \mathrm{~mL} / \mathrm{min}$ and consisted of $40 \mathrm{vol} \% \mathrm{~N}_{2}, 20 \mathrm{vol} \%$ $\mathrm{H}_{2} \mathrm{O}, 20$ vol\% $\mathrm{H}_{2}, 10$ vol\% $\mathrm{CO}$ and 10 vol\% $\mathrm{CO}_{2}$. Prior to reaction, the catalyst was reduced in a mixture of $5 \mathrm{vol} \%$ $\mathrm{H}_{2}$ in $\mathrm{N}_{2}$ under heating from 293 to $453 \mathrm{~K}$ at a rate of $2 \mathrm{~K} / \mathrm{min}$.

The aerobic oxidation of benzyl alcohol was carried out as previously reported [42]. A round-bottle flask $(25 \mathrm{~mL})$ was charged with $100 \mathrm{mg}$ of catalyst, $1 \mathrm{mmol}$ of benzyl alcohol and $9.9 \mathrm{~mL}$ of toluene. Some experiments were carried out in the presence of $40 \mathrm{mg} \mathrm{NaOH}$. In such case, the catalyst amount was kept at $50 \mathrm{mg}$ to avoid complete conversion under otherwise similar conditions. Molecular oxygen was bubbled through the reaction mixture at a flow rate of $20 \mathrm{~mL} / \mathrm{min}$. The resulting mixture was then heated at $373 \mathrm{~K}$ for $1 \mathrm{~h}$ and cooled to room temperature. The reaction products were analyzed by a Shimadzu QP 5050 GC-MS (CP-Sil 8CB, $\left.50 \mathrm{~m} \times 0.32 \mathrm{~mm}, d_{\mathrm{f}}=0.15 \mu \mathrm{m}\right)$.

\section{Results and Discussion}

Figure 1 shows representative transmission electron micrographs of $\mathrm{CeO}_{2}$ nanorods and nanocubes. The ceria rods have a typical width of $6.5 \pm 1.6 \mathrm{~nm}$ with a broad length distribution between 30 and $200 \mathrm{~nm}$. The ceria nanocubes have a size distribution ranging from 20 to $60 \mathrm{~nm}$. The exposed surfaces for $\mathrm{CeO}_{2}$ nanorods have mostly been confirmed as $\{110\}$ and $\{100\}$ planes [26, 30, 41]. Although the $d$-spacing along the long side of $\mathrm{CeO}_{2}$ (rod) of $0.31 \mathrm{~nm}$ by analysis of our TEM images suggests the presence of $\{111\}$ planes in line with recent other work [43], we adopt here the assignment of $\{110\}$ planes. A more detailed EM analysis would be necessary to resolve this issue for our ceria nanorods. The surface of $\mathrm{CeO}_{2}$ (rod) exhibits a defective structure, which is thought to be due to the presence of oxygen vacancies in the
Fig. 1 Transmission electron micrographs of $\mathbf{a}, \mathbf{b} \mathrm{CeO}_{2}$ (rod) and $\mathbf{c}, \mathbf{d ~} \mathrm{CeO}_{2}$ (cube)
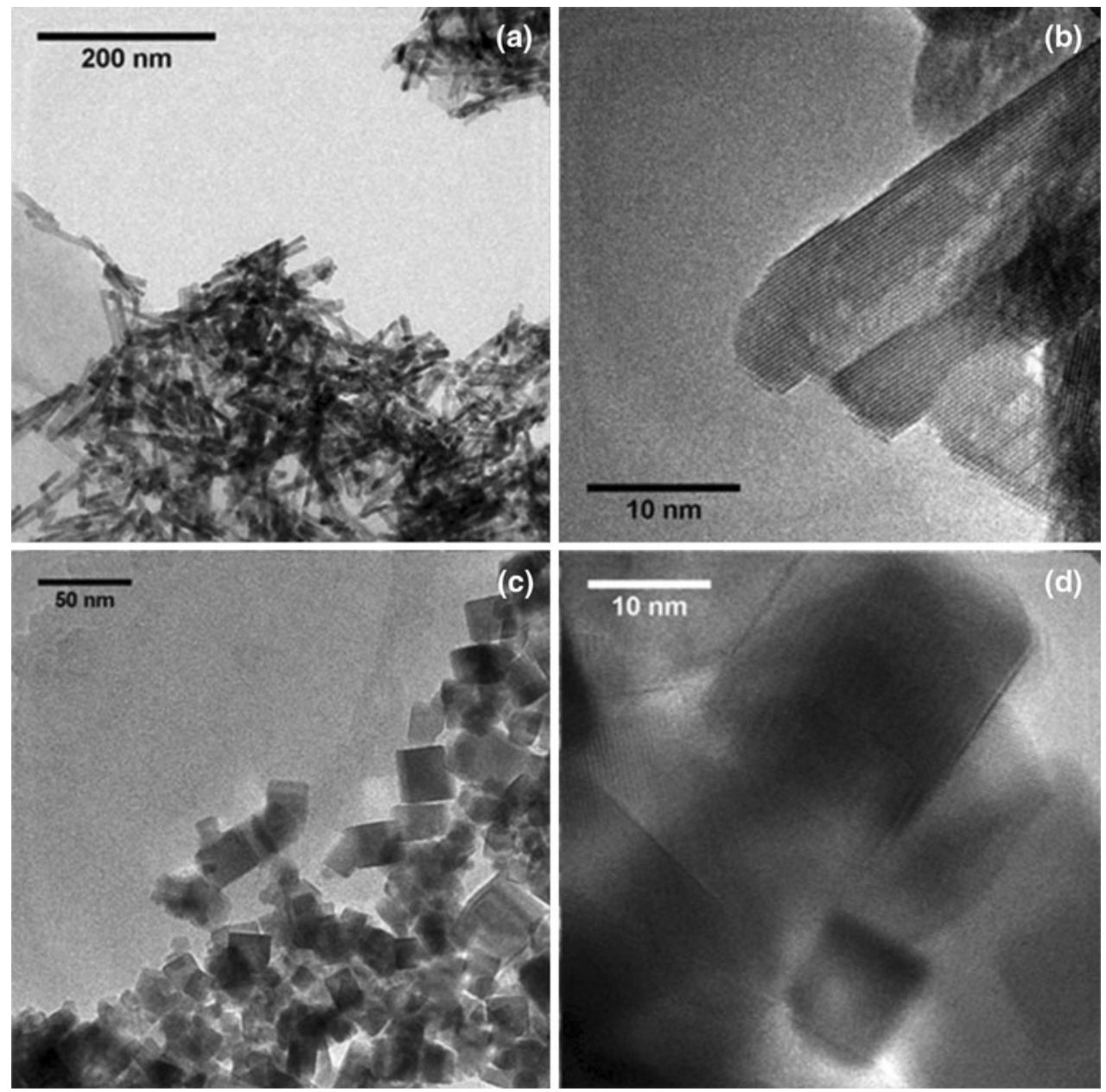
surface. The $\{100\}$ plane with a $d$-spacing of $0.27 \mathrm{~nm}$ dominates on $\mathrm{CeO}_{2}$ (cube) [30]. The crystallite sizes determined by application of Scherrer's equation are 8 and $35 \mathrm{~nm}$ for $\mathrm{CeO}_{2}$ (rod) and $\mathrm{CeO}_{2}$ (cube), respectively. The reason for the lower crystallite size of the $\mathrm{CeO}_{2}$ (rod) is the lower synthesis temperature compared to the due to their synthesis at lower temperature than employed for $\mathrm{CeO}_{2}$ (cube). This difference is consistent with the BET surface areas of $24 \mathrm{~m}^{2} / \mathrm{g}$ for $\mathrm{CeO}_{2}$ (cube) and $110 \mathrm{~m}^{2} / \mathrm{g}$ for $\mathrm{CeO}_{2}(\operatorname{rod})$.

Figure 2 displays representative transmission electron micrographs of gold nanoparticles supported by $\mathrm{CeO}_{2}$ (rod) and $\mathrm{CeO}_{2}$ (cube) at a metal loading of $2 \mathrm{wt} \%$. The size of the gold particles is in the range of $2-8 \mathrm{~nm}$. The average particle size is $4.6 \pm 1.5$ and $4.7 \pm 1.5 \mathrm{~nm}$ for $\mathrm{Au} /$ $\mathrm{CeO}_{2}$ (rod) and $\mathrm{Au} / \mathrm{CeO}_{2}$ (cube), respectively. The values are close to the particle size of $4.0 \mathrm{~nm}$ determined for a 2 wt $\%$ Au supported on polyhedral ceria [11]. Most gold nanoparticles have a pyramidal shape. This has led others to propose that the atoms in the top layers of such particles are metallic, while those atoms that form the interface with the support are oxidic [44-46].
Upon cyanide leaching of these materials, the gold loading has decreased substantially (Table 1). The leached $\mathrm{Au} / \mathrm{CeO}_{2}$ (rod) catalyst contains $0.38 \mathrm{wt} \% \mathrm{Au}$. The gold loading in $\mathrm{Au} / \mathrm{CeO}_{2}$ (cube)-CN is lower than the detection limit of $0.01 \mathrm{wt} \%$. These results are in qualitative agreement with those obtained by $\mathrm{Si}$ and Flytzani-Stephanopoulos [26]. The electron micrographs of both leached catalysts do not show gold nanoparticles anymore, indicating that leaching is effective in removing the large nanoparticles in the parent materials. These results are in agreement with our earlier reported results [11].

In order to obtain more insight into nature of the interaction of gold with the ceria surfaces, the leaching procedure was carried out for a set of ceria nanorod- and nanocube-supported catalysts with varying gold loading. Table 1 shows that the amount of gold retained by $\mathrm{CeO}_{2}$ (rod) upon leaching does not strongly depend on the gold loading of the parent material. For a set of $\mathrm{Au} /$ $\mathrm{CeO}_{2}$ (cube) gold was completely removed by cyanide leaching. To establish at what stage of the preparation the specific interaction of gold with the ceria surface is brought about, cyanide leaching was carried out on a $\mathrm{Au} / \mathrm{CeO}_{2}$ (rod)
Fig. 2 Transmission electron micrographs of a $\mathrm{Au} / \mathrm{CeO}_{2}$ (rod), b $\mathrm{Au} / \mathrm{CeO}_{2}$ (rod)-CN, c Au/ $\mathrm{CeO}_{2}$ (cube) and $\mathbf{d ~ A u / ~}$ $\mathrm{CeO}_{2}$ (cube)-CN
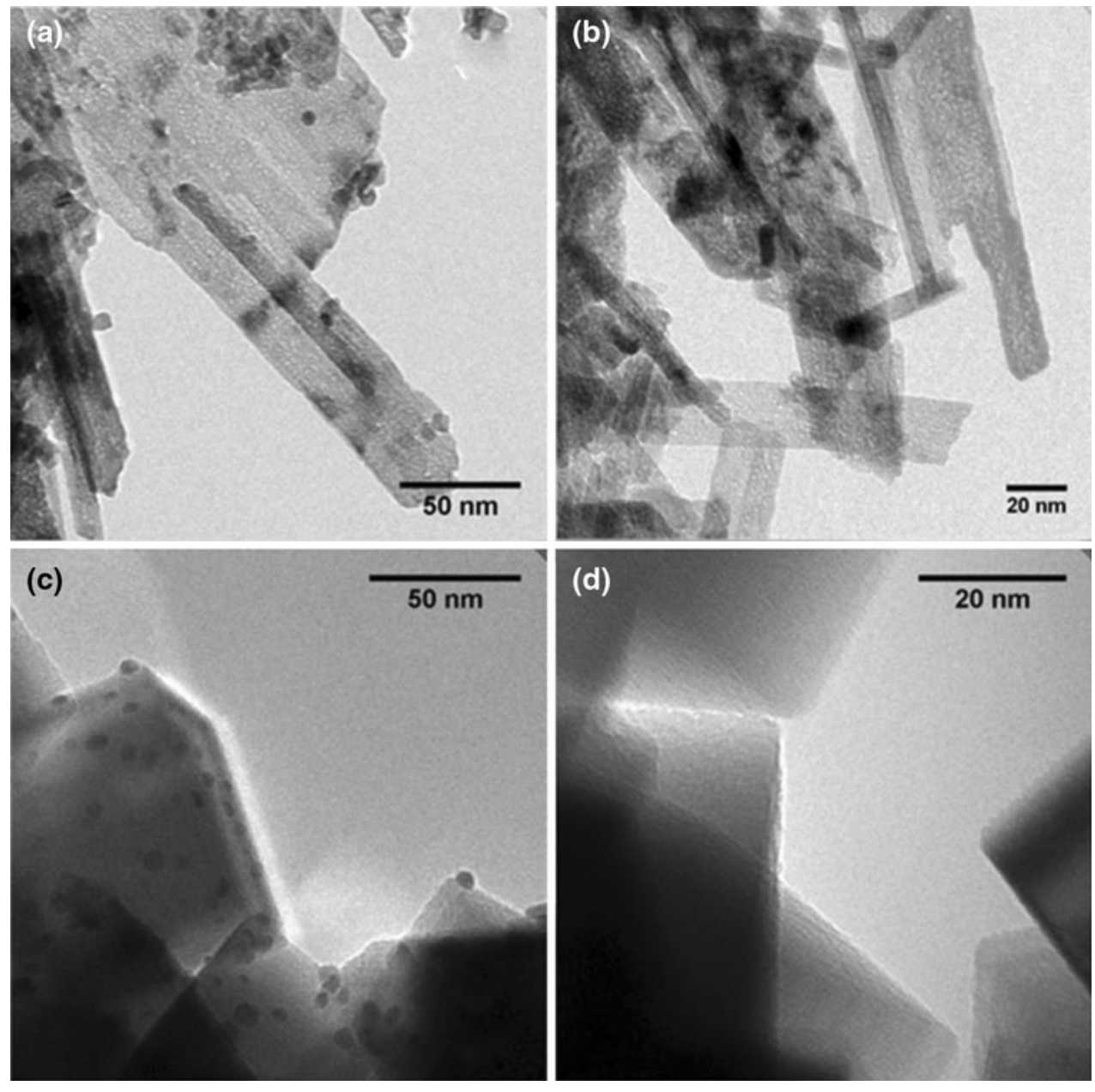
Table 1 Metal loading of ceria-supported gold catalysts before and after leaching by a $\mathrm{NaCN}$ solution

\begin{tabular}{llll}
\hline Support & Pretreatment & \multicolumn{2}{l}{ Au loading (wt\%) } \\
\cline { 3 - 4 } & & Before leaching & After leaching \\
\hline $\mathrm{CeO}_{2}$ (rod) & Calcination & 0.79 & 0.29 \\
& & 2.01 & 0.38 \\
& & 3.30 & 0.35 \\
& & 6.02 & 0.22 \\
& Drying & 2.01 & 0.08 \\
$\mathrm{CeO}_{2}$ (cube) & Calcination & 1.90 & $<0.01$ \\
& & 4.29 & $<0.01$ \\
\hline
\end{tabular}

catalyst that had not been calcined after deposition-precipitation. Instead, the precursor has been dried at $333 \mathrm{~K}$. In this case, the gold loading after leaching was only 0.086 $\mathrm{wt} \%$ indicating that the strong metal-support interaction is brought about by calcination of the catalyst precursor. In this material gold is predominantly present as gold hydroxides. The function of the cyanide ions is then to complex the gold cations. A final experiment was done to exclude the possibility that the strong interaction between gold and the surface of $\mathrm{CeO}_{2}$ (rod) is brought about during the leaching process. To this end, cyanide leaching of $\mathrm{Au} /$ $\mathrm{CeO}_{2}$ (rod) was carried out followed by filtration. The filtrate was brought in contact with fresh $\mathrm{CeO}_{2}(\mathrm{rod})$ and was then filtered again. The gold loading of this material was $0.089 \mathrm{wt} \%$. The finding that the amount of gold adsorbed in this case is close to the amount remaining after leaching of the non-calcined catalyst may indicate that part of the gold on $\mathrm{CeO}_{2}$ is adsorbed at vacancies in the ceria surface during such treatments.

Hydrogen TPR measurements were carried out to determine differences in the reducibility of the catalysts. Figure 3 contains the TPR traces for the catalysts and Table 2 collects the maxima of the TPR traces and the total hydrogen consumption for the supports and the catalysts. The higher hydrogen uptake of $\mathrm{CeO}_{2}(\mathrm{rod})(571 \mu \mathrm{mol} / \mathrm{g})$ than that of $\mathrm{CeO}_{2}$ (cube) $(121 \mu \mathrm{mol} / \mathrm{g})$ is due to the difference in surface area. The reduction of the support materials (not shown) takes place in the region $723-823 \mathrm{~K}$ in agreement with results for conventional $\mathrm{CeO}_{2}$ [47]. The reduction of $\mathrm{Au} / \mathrm{CeO}_{2}$ (rod) and $\mathrm{Au} / \mathrm{CeO}_{2}$ (rod)-CN occurs around $430 \mathrm{~K}$. The hydrogen uptake takes place in a much broader temperature range for the former catalyst than for the latter. The hydrogen uptake of $\mathrm{Au} / \mathrm{CeO}_{2}$ (rod) is slightly higher than that of the support, whereas the uptake of $\mathrm{Au} /$ $\mathrm{CeO}_{2}$ (rod)- $\mathrm{CN}$ is close to the value determined for the support. This result confirms that nearly all surface oxygen species of ceria can be reduced at low temperature, even in the presence of a relatively small amount of gold as in $\mathrm{Au} /$ $\mathrm{CeO}_{2}($ rod $)-\mathrm{CN}[18,48]$. The somewhat higher uptake of

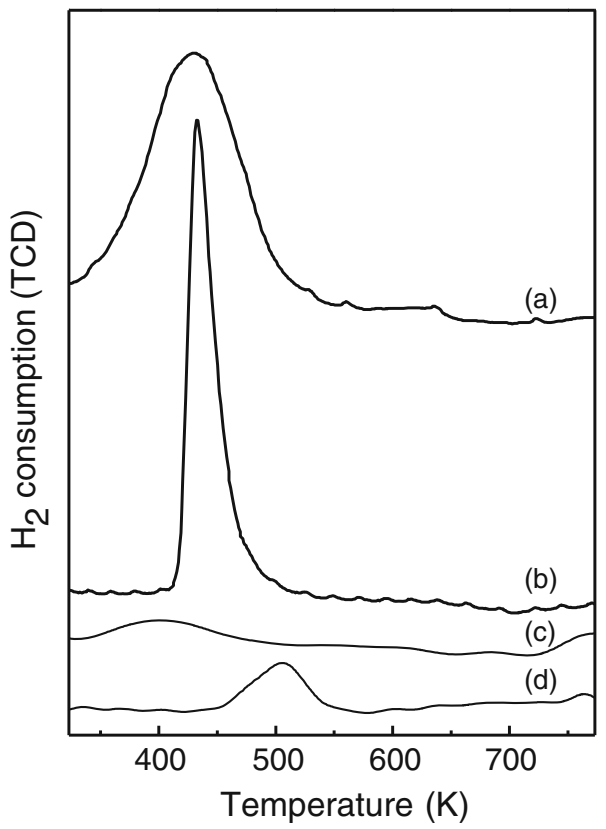

Fig. 3 TPR traces of hydrogen consumption (positive means consumption) for $a \mathrm{Au} / \mathrm{CeO}_{2}(\operatorname{rod}), b \mathrm{Au} / \mathrm{CeO}_{2}(\operatorname{rod})-\mathrm{CN}, c \mathrm{Au} / \mathrm{CeO}_{2}$ (cube) and $d \mathrm{Au} / \mathrm{CeO}_{2}$ (cube)-CN

Table 2 Maximum of hydrogen reduction peak and total hydrogen uptake during TPR of supports and catalysts

\begin{tabular}{lll}
\hline Sample & $T_{\max }(\mathrm{K})$ & $\begin{array}{l}\text { Hydrogen uptake } \\
(\mu \mathrm{mol} / \mathrm{g})\end{array}$ \\
\hline $\mathrm{CeO}_{2}$ (rod) & 773 & 570 \\
$\mathrm{CeO}_{2}($ cube $)$ & 773 & 121 \\
$\mathrm{Au} / \mathrm{CeO}_{2}$ (rod) & 429 & 670 \\
$\mathrm{Au} / \mathrm{CeO}_{2}$ (rod)-CN & 433 & 541 \\
$\mathrm{Au} / \mathrm{CeO}_{2}$ (cube) & 403 & 44 \\
$\mathrm{Au} / \mathrm{CeO}_{2}$ (cube)-CN & 513 & 45 \\
\hline
\end{tabular}

$\mathrm{Au} / \mathrm{CeO}_{2}$ (rod) is probably due to the reduction of gold surface oxides. Typically, calcination of the gold hydroxide precursor phase results in gold metal nanoparticles with some residual surface oxygen [49]. As a large fraction of gold is already reduced, hydrogen atoms from $\mathrm{H}_{2}$ dissociation by gold spill over to the ceria support and reduce its surface [50-52]. The hydrogen uptake for the cyanideleached $\mathrm{Au} / \mathrm{CeO}_{2}$ (rod) takes place in a much smaller temperature range. This indicates that the gold particles are oxidic and that they are more difficult to reduce than the gold nanoparticles in the parent material. The reduction in $\mathrm{Au} / \mathrm{CeO}_{2}$ (cube) takes place at relatively low temperature. Interestingly, the hydrogen uptake is substantially lower than that of the parent ceria nanocube support. After cyanide leaching, a hydrogen uptake feature is observed around $525 \mathrm{~K}$. It might be that this latter feature is due to the partial surface reduction of $\mathrm{CeO}_{2}$ (cube) facilited by the 
reduction of the residual gold cations in this surface to metallic particles. The total uptake of $\mathrm{Au} / \mathrm{CeO}_{2}$ (cube)-CN is similar to that of $\mathrm{Au} / \mathrm{CeO}_{2}$ (cube). It should be noted that the TPR traces of the nanocube-supported catalysts show a slight increase of the hydrogen consumption at the high temperature end. This may indicate that hydrogen spillover processes are less efficient on the cube-shaped ceria surface planes than they are on the rod-shaped planes and complete surface reduction only occurs at high temperatures.

Figure 4 compares FTIR spectra after $\mathrm{CO}$ adsorption at $80 \mathrm{~K}$ for the various gold catalysts. The spectrum in the carbonyl region for the fresh $\mathrm{Au} / \mathrm{CeO}_{2}$ (rod) catalysts exhibits a broad band centered around $2130 \mathrm{~cm}^{-1}$ with shoulders at 2116 and $2207 \mathrm{~cm}^{-1}$. The band at $2130 \mathrm{~cm}^{-1}$ may be assigned to $\mathrm{CO}$ adsorbed to positively charged gold species $[19,53]$, but care has to be taken because this band overlaps with the band due to $\mathrm{CO}$ adsorption to $\mathrm{Ce}^{3+}$ centers [54, 55]. The band at $2116 \mathrm{~cm}^{-1}$ is due to the adsorption of CO to metallic gold [56]. Boccuzzi et al. [5759] have proposed that $\mathrm{CO}$ stretching band on gold nanoparticles in the range of $2106-2118 \mathrm{~cm}^{-1}$ relates to $\mathrm{CO}$ adsorption to corner sites. The band at $2207 \mathrm{~cm}^{-1}$ is likely due to $\mathrm{CO}$ adsorbed to $\mathrm{Au}^{3+}$ [55]. Figure 4 shows the corresponding IR spectrum of the calcined $\mathrm{Au} / \mathrm{CeO}_{2}$ (cube) catalyst. A strong band at $2117 \mathrm{~cm}^{-1}$ is observed, indicative of the presence of neutral gold nanoparticles [56]. The bands around 2130 and $2207 \mathrm{~cm}^{-1}$ present in the spectra of $\mathrm{Au} / \mathrm{CeO}_{2}$ (rod) are not observed, which suggests that this
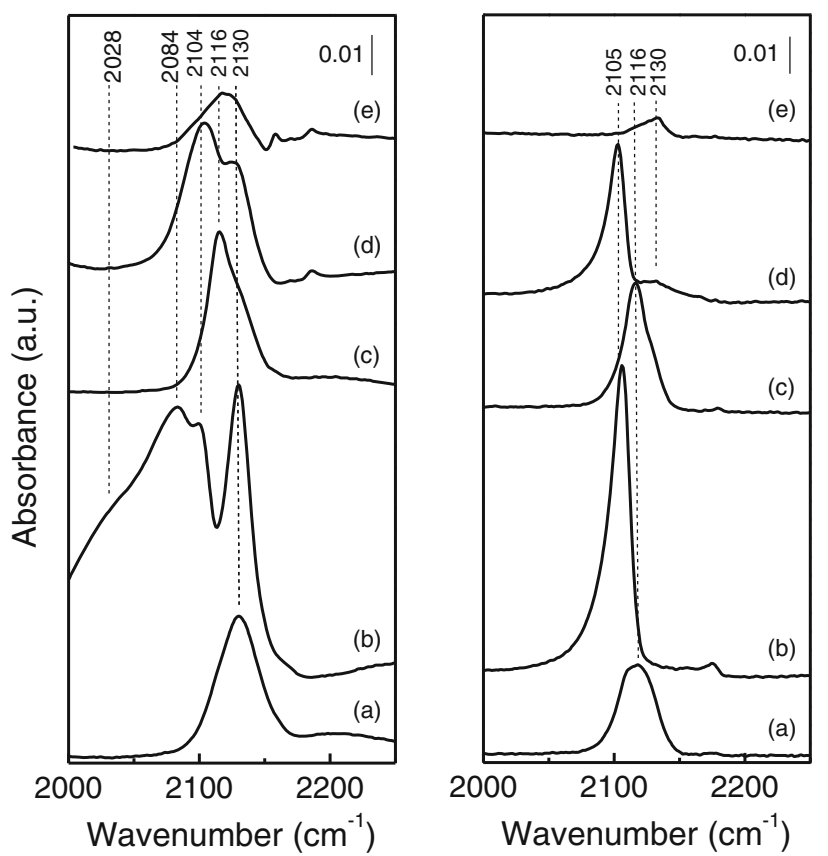

Fig. 4 FTIR spectra of adsorbed $\mathrm{CO}$ at $80 \mathrm{~K}$ of (left) $\mathrm{Au} / \mathrm{CeO}_{2}(\mathrm{rod})$ and (right) $\mathrm{Au} / \mathrm{CeO}_{2}$ (cube): $a$ fresh calcined catalyst, $b$ reduction at $393 \mathrm{~K}, c$ reoxidation at $423 \mathrm{~K}, d$ reduction at $773 \mathrm{~K}$ and $e$ reoxidation at $313 \mathrm{~K}$ sample does not contain cationic gold species. The absence of the band at $2130 \mathrm{~cm}^{-1}$ also shows that the surface of ceria nanocubes does not contain $\mathrm{Ce}^{3+}$ vacancies. These FTIR spectra considerably changed following reduction in $\mathrm{H}_{2}$ at $393 \mathrm{~K}$. The band at $2130 \mathrm{~cm}^{-1}$ becomes much more intense (Fig. 4), which should be due to the increased density of $\mathrm{Ce}^{3+}$ sites at the surface. New bands appear at 2028, 2084, and $2103 \mathrm{~cm}^{-1}$. The former two bands are assigned to $\mathrm{CO}$ adsorption on anionic gold clusters [56, 58, 59]. The latter band at $2103 \mathrm{~cm}^{-1}$ has been assigned to $\mathrm{CO}$ adsorption on well-reduced gold particles. This band replaces the one at $2116 \mathrm{~cm}^{-1}$, which has previously been assigned to $\mathrm{CO}$ adsorption on metallic gold in the presence of surface oxygen species [58]. This latter assignment agrees with the changes in the band's position upon reduction.

In contrast to these results, the corresponding spectrum (Fig. 4) of $\mathrm{Au} / \mathrm{CeO}_{2}$ (cube) does not show an increase of the band at $2130 \mathrm{~cm}^{-1}$. This corresponds to the earlier noted absence of reduction of the surface of $\mathrm{CeO}_{2}$ (cube) at low temperatures. More importantly, the observation of a single band for gold at $2105 \mathrm{~cm}^{-1}$ indicates that gold is present as reduced gold nanoparticles. The substantial difference in the IR spectra between $\mathrm{Au} / \mathrm{CeO}_{2}$ (cube) and $\mathrm{Au} / \mathrm{CeO}_{2}$ (rod) may be due to the presence of very finely dispersed gold clusters in strong interaction with the support in the latter catalyst. These particles are not observed by conventional bright-field TEM. The less likely alternative is that the nanoparticles visible by TEM in both catalysts behave completely different.

Upon exposure of the reduced catalysts to $\mathrm{O}_{2}$ at $313 \mathrm{~K}$ the band at $2116 \mathrm{~cm}^{-1}$ appeared again at the expense of the one around $2105 \mathrm{~cm}^{-1}$ in $\mathrm{Au} / \mathrm{CeO}_{2}$ (rod) and $\mathrm{Au} / \mathrm{CeO}_{2}$ (cube). This effect can be understood by the presence of surface oxygen adatoms and has been reported before for both ceria- and silica-supported gold nanoparticles [58, 60]. Another observation is the disappearance of the bands below $2100 \mathrm{~cm}^{-1}$. This could be due to the oxidation of the very fine clusters of gold on the ceria surface in $\mathrm{Au} /$ $\mathrm{CeO}_{2}$ (rod). To investigate the stability of the gold nanoparticles against sintering at high temperature, the sample was further reduced at $773 \mathrm{~K}$. In the case of $\mathrm{Au} / \mathrm{CeO}_{2}$ (rod) the bands at 2084 and $2103 \mathrm{~cm}^{-1}$ were recovered, but with a much lower intensity. This indicates that the gold clusters and particles have substantially sintered. Expectedly, the same shift of the band at $2117 \mathrm{~cm}^{-1}$ towards lower wavelength was observed after high-temperature reduction of $\mathrm{Au} / \mathrm{CeO}_{2}$ (cube). Also in this case the intensity is much lower, suggesting that the nanoparticles have grown in size.

Figure 5 contains the FTIR spectra for the leached $\mathrm{Au} /$ $\mathrm{CeO}_{2}$ catalysts. The spectrum of $\mathrm{Au} / \mathrm{CeO}_{2}$ (rod)-CN after reduction at $393 \mathrm{~K}$ contains only a weak feature around $2130 \mathrm{~cm}^{-1}$. After oxidation this band disappears. 
Reduction at $523 \mathrm{~K}$ results in the appearance of a dominant band around $2130 \mathrm{~cm}^{-1}$ due to surface $\mathrm{Ce}^{3+}$ states with a shoulder in the region $2105-2115 \mathrm{~cm}^{-1}$ due to reduced gold clusters. A weak feature around $2082 \mathrm{~cm}^{-1}$ is also observed. Reoxidation at $313 \mathrm{~K}$ results in the disappearance of all bands, indicating that the small gold particles were oxidized. Reduction at $773 \mathrm{~K}$ results in bands at 2103 and $2130 \mathrm{~cm}^{-1}$. Clearly, these particles are still very small, because reoxidation at $313 \mathrm{~K}$ erodes all bands. The corresponding spectra of $\mathrm{Au} / \mathrm{CeO}_{2}$ (cube)-CN show no bands for the fresh catalyst and after reduction at $393 \mathrm{~K}$. This agrees with the absence of a TPR feature below $513 \mathrm{~K}$ for this catalyst. After reduction at $523 \mathrm{~K}$ two prominent bands are observed with a much lower intensity than the other catalysts. The one at $2128 \mathrm{~cm}^{-1}$ is due to $\mathrm{Ce}^{3+}$ and the one at $2090 \mathrm{~cm}^{-1}$ should be due to very finely dispersed gold clusters. Similar to $\mathrm{Au} / \mathrm{CeO}_{2}$ (rod)-CN, these bands erode upon reoxidation, even after high temperature reduction. The observation of a CO IR band at $2090 \mathrm{~cm}^{-1}$ at this very low Au loading $(<0.01 \mathrm{wt} \%)$ points to a very high gold dispersion.

$\mathrm{X}$-ray absorption spectroscopy is a useful technique to obtain detailed information about the oxidation state and structure of small supported gold particles [61-65]. Au L $\mathrm{L}_{\mathrm{III}}$ near-edge spectra at room temperature, drying and reduction at various temperatures for $\mathrm{Au} / \mathrm{CeO}_{2}$ (rod), $\mathrm{Au} /$ $\mathrm{CeO}_{2}$ (rod)-CN and $\mathrm{Au} / \mathrm{CeO}_{2}$ (cube) are collected in Fig. 6. The dried $\mathrm{Au} / \mathrm{CeO}_{2}$ (rod) catalysts contain a whiteline at
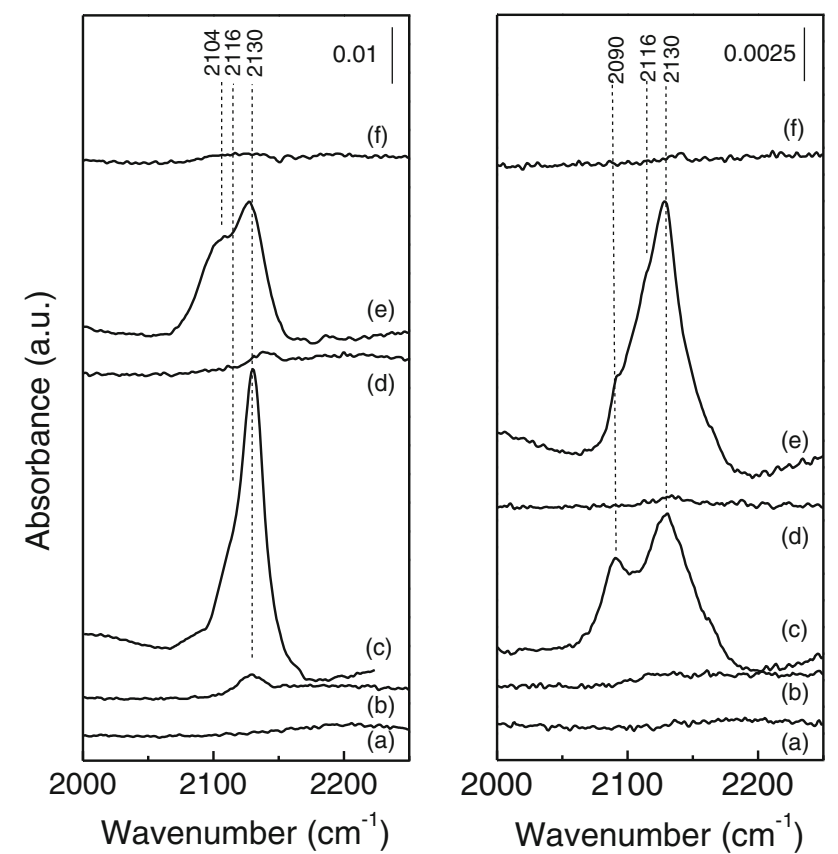

Fig. 5 FTIR spectra of adsorbed $\mathrm{CO}$ at $80 \mathrm{~K}$ of (left) $\mathrm{Au} / \mathrm{CeO}_{2}$ (rod)$\mathrm{CN}$ and (right) $\mathrm{Au} / \mathrm{CeO}_{2}$ (cube)-CN: $a$ fresh calcined catalyst, $b$ reduction at $393 \mathrm{~K}, c$ reduction at $423 \mathrm{~K}, d$ reoxidation at $423 \mathrm{~K}$, $e$ reduction at $773 \mathrm{~K}$ and $f$ reoxidation at $313 \mathrm{~K}$ $\sim 4 \mathrm{eV}$ above the edge, which is typical for $\mathrm{Au}^{3+}$ compounds [62]. This feature is more intense for the leached catalyst, indicating that a larger fraction of the gold atoms is in the cationic form. The whiteline is nearly absent for $\mathrm{Au} / \mathrm{CeO}_{2}$ (cube). Quantification of the amount of cationic gold was carried out by fitting the near-edge spectra by linear combinations of the XANES spectra of a gold foil and that of $\mathrm{Au} / \mathrm{CeO}_{2}(\mathrm{CN})$ [11]. The latter catalyst exclusively contained cationic gold as was evident from the EXAFS data analysis. The fraction of cationic gold in these materials as a function of the pretreatment conditions is given in Fig. 7. $\mathrm{Au} / \mathrm{CeO}_{2}$ (rod)- $\mathrm{CN}$ only contains cationic gold after preparation. Reduction at $393 \mathrm{~K}$ in $\mathrm{H}_{2}$ leads to a substantial decrease of the fraction of cationic gold. After reduction at $473 \mathrm{~K}$ only $9 \%$ cationic gold is left. To completely reduce the gold a temperature of $773 \mathrm{~K}$ is required. The fraction of cationic gold in $\mathrm{Au} / \mathrm{CeO}_{2}$ (rod) is initially much lower and then decreases similarly to $\mathrm{Au} /$ $\mathrm{CeO}_{2}$ (rod)-CN to very low levels at $773 \mathrm{~K}$. The fresh $\mathrm{Au} /$ $\mathrm{CeO}_{2}$ (cube) catalyst contains nearly $90 \%$ reduced gold atoms. This amount is nearly independent of the reduction temperature.

Table 3 shows the fit parameters of the Fourier transformed $k^{3}$-weighted EXAFS functions for $\mathrm{Au} / \mathrm{CeO}_{2}$ (rod), $\mathrm{Au} / \mathrm{CeO}_{2}$ (rod)-CN and $\mathrm{Au} / \mathrm{CeO}_{2}$ (cube). The FT functions of the EXAFS functions and the fits for the $\mathrm{Au} / \mathrm{CeO}_{2}$ (rod) catalysts are shown in Fig. 8. The FT EXAFS spectrum of dried $\mathrm{Au} / \mathrm{CeO}_{2}$ (rod) contains a $\mathrm{Au}-\mathrm{Au}$ shell at a coordination distance $(R)$ of $2.84 \AA$ with a coordination number $(\mathrm{CN})$ of 7.3. It also contains a small contribution of an oxygen backscatterer. These data point to the presence of metallic, yet not fully reduced gold nanoparticles with a particle size of about 3-4 nm [66]. Reduction at $523 \mathrm{~K}$ results in the disappearance of the Au-O shell and a small increase of the $\mathrm{Au}-\mathrm{Au}$ shell. Further reduction at $773 \mathrm{~K}$ induces a slightly higher $\mathrm{CN}$ and a longer bond distance. The spectrum of dried $\mathrm{Au} / \mathrm{CeO}_{2}$ (rod)-CN is completely different and can only be fitted by the inclusion of a $\mathrm{Ce}$ backscatterer next to a $\mathrm{Au}-\mathrm{O}$ shell. The first coordination shell contains $\sim 3$ oxygen atoms at $R=1.99 \AA$. The features at larger distance could not be fitted with a Au shell, as present in gold metal or in gold oxide $\left(\mathrm{Au}_{2} \mathrm{O}_{3}: 3.03\right.$ and $3.34 \AA$ [67]). This excludes the presence of small gold or gold oxide nanoparticles. Thus, a reasonable fit was obtained by including a Au-Ce shell at $R=3.27 \AA$. The structural parameters point to the presence of gold substituting at a cerium vacancy. These structural features were previously also found for leached $\mathrm{Au} / \mathrm{CeO}_{2}$ [11]. Reduction at $523 \mathrm{~K}$ results in a complete change of the structure around the gold atoms. The fit parameters show a $\mathrm{Au}-\mathrm{Au}$ contribution at $R=2.74 \AA$ with $\mathrm{CN}=4.0$ and a small contribution of oxygen at $R=1.95 \AA$. The Ce shell has disappeared. In agreement with the XANES results, this implies that the gold cations were reduced and have transformed into very 
Fig. 6 Near-edge spectra at the $\mathrm{Au} \mathrm{L}_{\mathrm{III}}$ edge of (left) $\mathrm{Au} /$ $\mathrm{CeO}_{2}$ (rod), (middle) $\mathrm{Au} /$ $\mathrm{CeO}_{2}$ (rod)-CN and (right) $\mathrm{Au} /$ $\mathrm{CeO}_{2}$ (cube). Top and bottom spectra are those of fresh $\mathrm{Au} /$ $\mathrm{CeO}_{2}$ (rod)-CN and a $\mathrm{Au}$ foil, respectively. The remaining spectra were obtained (from bottom to top) heating in $\mathrm{He}$ at $393 \mathrm{~K}$, reduction at $393 \mathrm{~K}$, reduction at $473 \mathrm{~K}$, reduction at $523 \mathrm{~K}$, reduction at $623 \mathrm{~K}$ and reduction at $773 \mathrm{~K}$
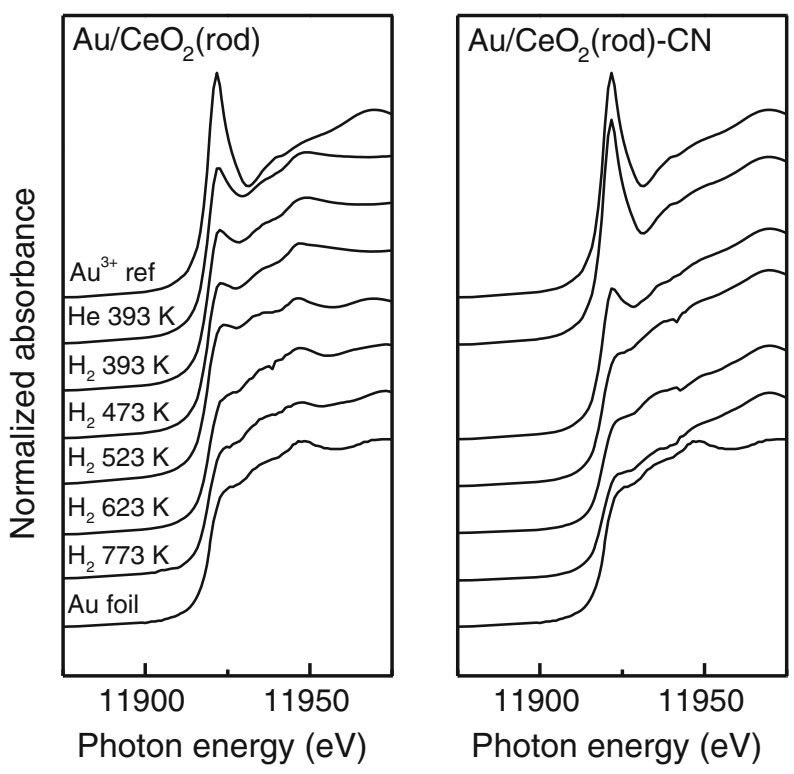

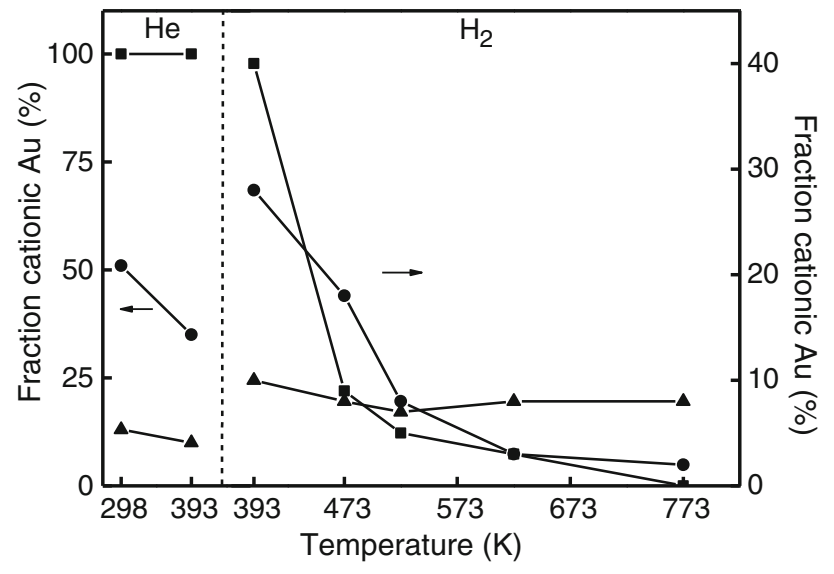

Fig. 7 Fraction of cationic gold after heating in $\mathrm{He}$ and $\mathrm{H}_{2}$ at various temperature as determined by analysis of the near-edge spectra of filled circle $\mathrm{Au} / \mathrm{CeO}_{2}$ (rod), filled square $\mathrm{Au} / \mathrm{CeO}_{2}(\mathrm{rod})-\mathrm{CN}$ and filled triangle $\mathrm{Au} / \mathrm{CeO}_{2}$ (cube)

small metallic clusters. The relatively short $\mathrm{Au}-\mathrm{Au}$ distance is in line with the small size of the particles in this catalyst $[66,68-70]$. The very low coordination number suggests that the particles have subnanometer dimensions [11, 61]. Upon reduction of the catalyst at $773 \mathrm{~K}, \mathrm{CN}$ and $R$ for the $\mathrm{Au}-\mathrm{Au}$ shell increase to 7.2 and $2.78 \AA$, respectively. These changes point to sintering of the small clusters to larger particles. The decreasing contribution of oxygen neighbours may be attributed to the decreasing interaction with the support or more complete reduction. The EXAFS fit parameters of Au/ $\mathrm{CeO}_{2}$ (cube) reduced at $523 \mathrm{~K}$ and $773 \mathrm{~K}$ evidence the presence of well-reduced gold nanoparticles of around $4 \mathrm{~nm}$.

To obtain more insight into the structure-activity relations of ceria-supported gold catalysts, we have compared the catalytic performance of the nanostructured gold catalysts in a number of commonly used oxidation and
Table 3 Fit parameters of $k^{3}$-weighted EXAFS spectra at the Au $\mathrm{L}_{\mathrm{III}}$ edge of $\mathrm{Au} / \mathrm{CeO}_{2}$ catalysts after different pretreatments

\begin{tabular}{lcllllll}
\hline Sample & Treatment & \multicolumn{5}{l}{ EXAFS fit parameters } \\
\cline { 3 - 7 } & & & Shell & $R(\AA)$ & $\mathrm{CN}$ & $\Delta \sigma^{2}\left(\AA^{2}\right)$ & $E_{0}(\mathrm{eV})$ \\
\hline $\mathrm{Au} / \mathrm{CeO}_{2}$ (rod) & $\mathrm{He}, 393 \mathrm{~K}$ & $\mathrm{O}$ & 1.96 & 0.7 & 0.005 & -6.2 \\
& & $\mathrm{Au}$ & 2.82 & 7.3 & 0.012 & \\
& $\mathrm{H}_{2}, 523 \mathrm{~K}$ & $\mathrm{Au}$ & 2.82 & 7.6 & 0.010 & -7.5 \\
& $\mathrm{H}_{2}, 773 \mathrm{~K}$ & $\mathrm{Au}$ & 2.84 & 8.0 & 0.011 & -7.1 \\
& $\mathrm{He}, 393 \mathrm{~K}$ & $\mathrm{O}$ & 1.99 & 3.4 & 0.007 & -8.9 \\
$\mathrm{Au} / \mathrm{CeO}_{2}$ (rod)- & & $\mathrm{Ce}$ & 3.27 & 3.8 & 0.012 & \\
$\mathrm{CN}$ & $\mathrm{H}_{2}, 523 \mathrm{~K}$ & $\mathrm{O}$ & 1.95 & 0.2 & 0.001 & -1.6 \\
& & $\mathrm{Au}$ & 2.74 & 4.0 & 0.013 & \\
& $\mathrm{H}_{2}, 773 \mathrm{~K}$ & $\mathrm{O}$ & 2.06 & 0.3 & 0.006 & -5.0 \\
& & $\mathrm{Au}$ & 2.78 & 7.2 & 0.015 & \\
& $\mathrm{H}_{2}, 523 \mathrm{~K}$ & $\mathrm{Au}$ & 2.86 & 8.7 & 0.009 & -8.6 \\
$\mathrm{Au} / \mathrm{CeO}_{2}$ (cube) & $\mathrm{H}_{2}, 773 \mathrm{~K}$ & $\mathrm{Au}$ & 2.86 & 8.5 & 0.010 & -7.9 \\
& &
\end{tabular}

$\Delta k=2.5-10.4 \AA^{-1}$; estimated error in $R \pm 0.02 \AA, N \pm 20 \%, \Delta \sigma^{2}$ $\pm 10 \%$; normalized residual of fits is between 30 and $36 \%$

hydrogenation reactions (Table 4). The nanostructured ceria supports were not active in $\mathrm{CO}$ oxidation at temperatures below $373 \mathrm{~K}$. In line with previous reports [25-27] the turnover frequencies (TOF) follow the trend $\mathrm{Au} /$ $\mathrm{CeO}_{2}$ (rod) $>\mathrm{Au} / \mathrm{CeO}_{2}$ (rod) $-\mathrm{CN}>\mathrm{Au} / \mathrm{CeO}_{2}$ (cube). The leached counterpart of $\mathrm{Au} / \mathrm{CeO}_{2}$ (cube) does not show any activity. To calculate the TOFs the dispersion for the nonleached catalysts was determined from the TEM particle size, while that of $\mathrm{Au} / \mathrm{CeO}_{2}$ (rod)- $\mathrm{CN}$ was assumed to be one. We expect that the $\mathrm{Au} / \mathrm{CeO}_{2}$ (rod) contains also very dispersed gold cations or clusters that were not imaged by EM analysis. As these cations are stable under the oxidizing reaction conditions, the TOF for $\mathrm{Au} / \mathrm{CeO}_{2}$ (rod) 
Fig. 8 Experimental (solid line) and fitted (dotted points) FT EXAFS functions of (left) $\mathrm{Au} / \mathrm{CeO}_{2}$ (rod)- $\mathrm{CN}$ and (right) $\mathrm{Au} / \mathrm{CeO}_{2}$ (rod) after drying at $393 \mathrm{~K}$ and reduction at increasing temperatures. The corresponding spectrum of a $\mathrm{Au}$ foil is included
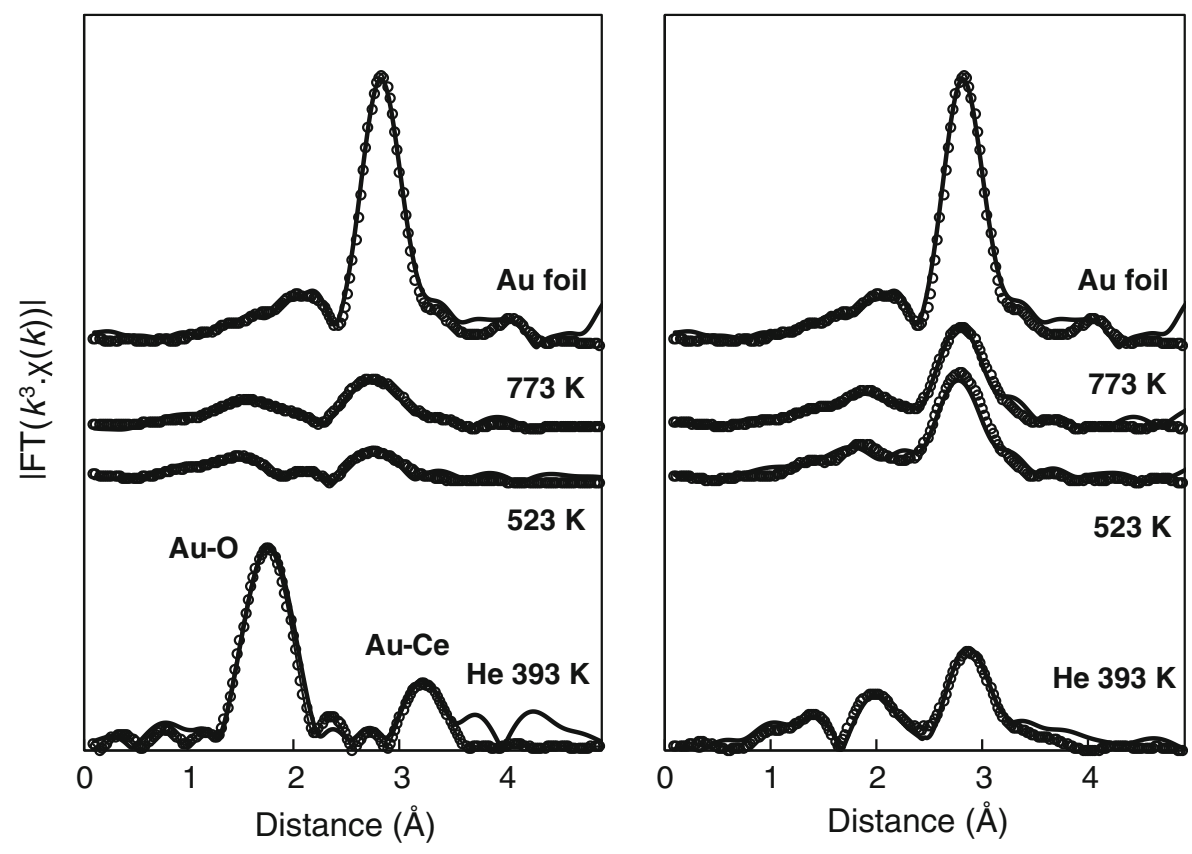

should be a lower bound. Nonetheless, the activity of $\mathrm{Au} /$ $\mathrm{CeO}_{2}$ (rod) is substantially higher than that of $\mathrm{Au} /$ $\mathrm{CeO}_{2}$ (rod)-CN. Moreover, $\mathrm{Au} / \mathrm{CeO}_{2}$ (rod) is much more active than $\mathrm{Au} / \mathrm{CeO}_{2}$ (cube), which contains fully reduced gold nanoparticles of the same dispersion. At room temperature, $\mathrm{Au} / \mathrm{CeO}_{2}$ (rod) is the only catalyst showing activity in $\mathrm{CO}$ oxidation (conversion of $11 \%$ ).

To understand the importance of the nature of the gold phase in more detail, we compared the $\mathrm{CO}$ oxidation activities of the two nanorod-supported gold catalysts after different treatments. $\mathrm{CO}$ oxidation was carried out in ramping mode $(5 \mathrm{~K} / \mathrm{min})$ between room temperature and $373 \mathrm{~K}$. Table 5 compares the CO conversion at $313 \mathrm{~K}$ during consecutive runs and after intermittent reduction at various temperatures. The activities of these catalysts increased upon consecutive reaction runs. Reduction at $373 \mathrm{~K}$ and higher had a slightly negative effect on the $\mathrm{CO}$ conversion of $\mathrm{Au} / \mathrm{CeO}_{2}$ (rod) up to $623 \mathrm{~K}$. Reduction of this

Table 4 Catalytic activities of supports and gold-containing catalysts

\begin{tabular}{lcll}
\hline Sample & $\begin{array}{l}\mathrm{CO} \\
\text { oxidation }^{\mathrm{a}} \\
\mathrm{TOF}^{\left(\mathrm{h}^{-1}\right)}\end{array}$ & $\begin{array}{l}\text { Benzylic alcohol } \\
\text { oxidation }^{\mathrm{b}} \\
\mathrm{TOF}^{-1} \mathrm{~h}^{-1}\end{array}$ & $\begin{array}{l}\text { Butadiene } \\
\text { hydrogenation } \\
\text { TOF }\left(\mathrm{s}^{-1}\right)\end{array}$ \\
\hline $\mathrm{Au} / \mathrm{CeO}_{2}$ (rod) & 216 & $59\left(108^{\mathrm{d}}\right)$ & 0.21 \\
$\mathrm{Au} / \mathrm{CeO}_{2}$ (rod)-CN & 83 & 0 & 0.47 \\
$\mathrm{Au} / \mathrm{CeO}_{2}$ (cube) & 3 & $14\left(193^{\mathrm{d}}\right)$ & 0.03 \\
$\mathrm{Au} / \mathrm{CeO}_{2}$ (cube)-CN & 0 & 0 & 0.00 \\
\hline
\end{tabular}

a $1 \mathrm{vol} \% \mathrm{CO}$ and $1 \mathrm{vol} \% \mathrm{O}_{2}$ at $313 \mathrm{~K}$

b Liquid phase: $1 \mathrm{mmol}$ benzylic alcohol, $100 \mathrm{mg}$ catalyst, $373 \mathrm{~K}$

c 2 vol\% 1,3-butadiene in $\mathrm{H}_{2} ; 383 \mathrm{~K}$

d $50 \mathrm{mg}$ catalyst; $40 \mathrm{mg} \mathrm{NaOH}$ added catalyst at $773 \mathrm{~K}$ led to a strong decrease of the activity. Reduction increases the activity of the leached catalyst. Also for this catalyst, a pronounced decrease in CO conversion was noted upon reduction at $773 \mathrm{~K}$. This result is consistent with previous reports that the $\mathrm{CO}$ oxidation activity on gold catalyst is very sensitive to the treatments [71, 72]. Clearly, the chemical properties of gold clusters are changing with different pre-treatment conditions.

Figure 9 shows the $\mathrm{CO}$ conversion during the WGS reaction as a function of temperature for $\mathrm{Au} / \mathrm{CeO}_{2}$ (rod) and $\mathrm{Au} / \mathrm{CeO}_{2}$ (rod)-CN. The $\mathrm{CO}$ conversion of $\mathrm{Au} / \mathrm{CeO}_{2}$ (cube) was below $2 \%$ and did not depend on temperature. The catalysts were reduced at $453 \mathrm{~K}$ prior to reaction. At $473 \mathrm{~K}$ the $\mathrm{CO}$ conversion was $2.5 \%$ for $\mathrm{Au} / \mathrm{CeO}_{2}(\operatorname{rod})$. With temperature the $\mathrm{CO}$ conversion increased to about $18 \%$ at $673 \mathrm{~K}$. Following the subsequent decrease of the reaction temperature the activities became slightly lower than during the increasing temperature mode. The initial $\mathrm{CO}$

Table $5 \mathrm{CO}$ conversion at $313 \mathrm{~K}$ of $\mathrm{Au}$ supported on rod-shaped $\mathrm{CeO}_{2}$ as a function of pretreatment

\begin{tabular}{lll}
\hline Sample & \multicolumn{2}{l}{$\mathrm{CO}$ conversion $(\%)$} \\
\cline { 2 - 3 } & $\mathrm{Au} / \mathrm{CeO}_{2}$ (rod) & $\mathrm{Au} / \mathrm{CeO}_{2}$ (rod)-CN \\
\hline Run 1 & 44 & 3 \\
Run 2 & 46 & 11 \\
Run 3 & 51 & 12 \\
Reduced 373 K & 55 & 18 \\
Reduced $473 \mathrm{~K}$ & 48 & 16 \\
Reduced 623 K & 41 & 16 \\
Reduced $773 \mathrm{~K}$ & 17 & 5 \\
\hline
\end{tabular}


conversion of $\mathrm{Au} / \mathrm{CeO}_{2}$ (rod)- $\mathrm{CN}$ at $473 \mathrm{~K}$ was about two times higher than that of $\mathrm{Au} / \mathrm{CeO}_{2}$ (rod). The $\mathrm{CO}$ conversion increased to about $15 \%$ at a temperature of $553 \mathrm{~K}$. At this temperature the conversion difference with $\mathrm{Au} /$ $\mathrm{CeO}_{2}$ (rod) was a factor two. A further increase of the temperature led to severe deactivation and only after reaction above $633 \mathrm{~K}$ a small activity increase was noted. During the decreasing temperature branch the activity of the catalyst was substantially lower than during the increasing temperature branch. To compare the intrinsic activities of these two catalysts, we assume that the dispersion of $\mathrm{Au} / \mathrm{CeO}_{2}$ (rod) is that of the fresh catalysts (4.6 nm, $D=28 \%$ ). Reduction at $523 \mathrm{~K}$ of Au/ $/ \mathrm{CeO}_{2}(\mathrm{rod})$ $\mathrm{CN}$ results in a coordination of 4 . This implies that (nearly) all gold atoms can participate in the catalysis $(D=100 \%)$. A rough approximation learns that $\mathrm{Au} / \mathrm{CeO}_{2}(\operatorname{rod})-\mathrm{CN}$ is about four times more active per surface gold atom than $\mathrm{Au} / \mathrm{CeO}_{2}$ (rod) at a temperature of $533 \mathrm{~K}$. This difference is likely due to the dependence of the oxygen surface coverage as a function of the particle size. Small particles can become more easily oxidized, as is also evident from the above-described CO IR results. Deng et al. [74] have found that gold agglomeration during WGS operation results in loss of surface oxygen and might be an explanation for the loss in activity. The temperature-programmed experiments were repeated with the difference that during the decreasing temperature branch $20 \mathrm{ppm} \mathrm{H}_{2} \mathrm{~S}$ was added to the

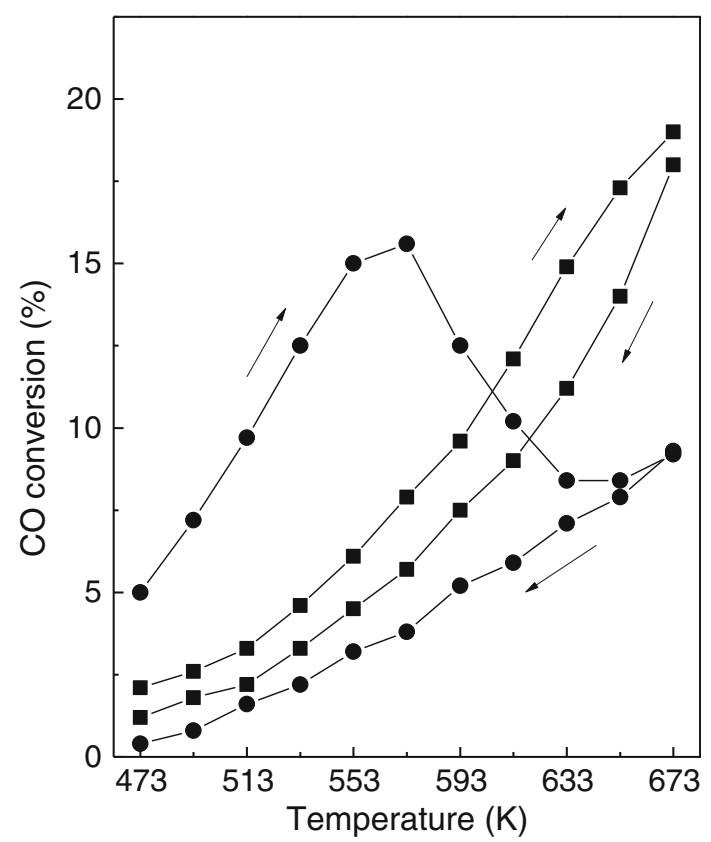

Fig. 9 CO conversion during WGS reaction as a function of temperature of a mixture of $40 \mathrm{vol} \% \mathrm{~N}_{2}, 20 \mathrm{vol} \% \mathrm{H}_{2} \mathrm{O}, 20$ vol\% $\mathrm{H}_{2}, 10 \mathrm{vol} \% \mathrm{CO}$ and $10 \mathrm{vol} \% \mathrm{CO}_{2}$ of filled circles $\mathrm{Au} / \mathrm{CeO}_{2}$ (rod) and filled squares $\mathrm{Au} / \mathrm{CeO}_{2}$ (rod)- $\mathrm{CN}$ (arrows indicate temperature gradient) reactor feed. This had a detrimental effect on the catalytic activity and no conversion of $\mathrm{CO}$ was observed anymore.

Further experiments concentrated on the role of cationic gold in the WGS reaction. X-ray absorption spectroscopy was employed at 373 and $473 \mathrm{~K}$ during the WGS reaction. Flytzani-Stephanopoulos and co-workers [73] already performed such an in situ study and therefore we only briefly discuss these results. Whereas calcined $\mathrm{Au} /$ $\mathrm{CeO}_{2}$ (rod)-CN only contained cationic gold (Fig. 6), exposure of this catalyst to an atmosphere of $\mathrm{CO} / \mathrm{H}_{2} \mathrm{O}$ for $15 \mathrm{~min}$ at $373 \mathrm{~K}$ resulted in the complete reduction of the gold phase (Fig. 10). The reduction is more extensive than upon treatment in $\mathrm{H}_{2}$ at $393 \mathrm{~K}$. Treatment in $20 \% \mathrm{O}_{2} / \mathrm{He}$ led to reoxidation of only $20 \%$ of the gold atoms. This shows that the initially isolated gold cations have agglomerated into small Au clusters that can only be partially reoxidized [73]. Under similar conditions $\mathrm{Au} /$ $\mathrm{CeO}_{2}$ (rod) contained only metallic gold. EXAFS spectra recorded for $\mathrm{Au} / \mathrm{CeO}_{2}$ (rod) after prolonged WGS at $473 \mathrm{~K}$ showed a constant $\mathrm{Au}-\mathrm{Au}$ coordination number of 7.4, which agrees well with the results reported in Table 3. A similar analysis for $\mathrm{Au} / \mathrm{CeO}_{2}$ (rod)-CN gave a $\mathrm{Au}-\mathrm{Au}$ coordination number of 4.4 under WGS conditions. These results show that the gold phases in these materials under WGS conditions are very similar to the gold phases after reduction in $\mathrm{H}_{2}$. Based on the $\mathrm{CO}$ conversion measured during the in situ EXAFS experiments, we again find a higher TOF of $2.2 \mathrm{~mol}_{\mathrm{CO}} / \mathrm{mol}_{\mathrm{Au}} \cdot \min$ for $\mathrm{Au} / \mathrm{CeO}_{2}(\mathrm{rod})-\mathrm{CN}$ than the value of $1.3 \mathrm{~mol}_{\mathrm{CO}} / \mathrm{mol}_{\mathrm{Au}} \cdot \mathrm{min}$ for $\mathrm{Au} / \mathrm{CeO}_{2}$ (rod).

Besides gas-phase $\mathrm{CO}$ oxidation, gold catalysts have also been reported to be excellent catalyst for selective oxidation of alcohols with molecular oxygen [2, 42, 74]. Table 5 includes the TOFs of the fresh catalysts based on the amount of benzylic alcohol converted and the total amount of gold. The selectivity to benzaldehyde was $>99 \%$. The TOF of $\mathrm{Au} / \mathrm{CeO}_{2}$ (rod) is substantially higher $\left(59 \mathrm{~h}^{-1}\right)$ than that of $\mathrm{Au} / \mathrm{CeO}_{2}$ (cube) at $14 \mathrm{~h}^{-1}$. As the use of base is known to improve the activity in alcohol oxidation of these catalysts, we carried out similar experiments in the presence of a small amount of $\mathrm{NaOH}$. In such case, the activity of $\mathrm{Au} / \mathrm{CeO}_{2}$ (rod) and $\mathrm{Au} / \mathrm{CeO}_{2}$ (cube) became 108 and $193 \mathrm{~h}^{-1}$, respectively.

Figure 11 shows the activities of the various catalysts in the hydrogenation of 1,3-butadiene at $383 \mathrm{~K}$. The catalysts underwent severe deactivation during the reaction. The butenes selectivity at $383 \mathrm{~K}$ remained close to $99 \%$ in all cases. The deactivation with time on stream has been reported previously [75] and is likely due to the relatively strong adsorption of butadiene to the catalyst surface. TOFs were calculated based on the butadiene conversion after $3 \mathrm{~h}$ time on stream. The TOF of $\mathrm{Au} / \mathrm{CeO}_{2}(\operatorname{rod})\left(0.21 \mathrm{~s}^{-1}\right)$ is seven times higher than that of $\mathrm{Au} / \mathrm{CeO}_{2}$ (cube) $\left(0.03 \mathrm{~s}^{-1}\right)$ at the same gold loading and particle size. The 


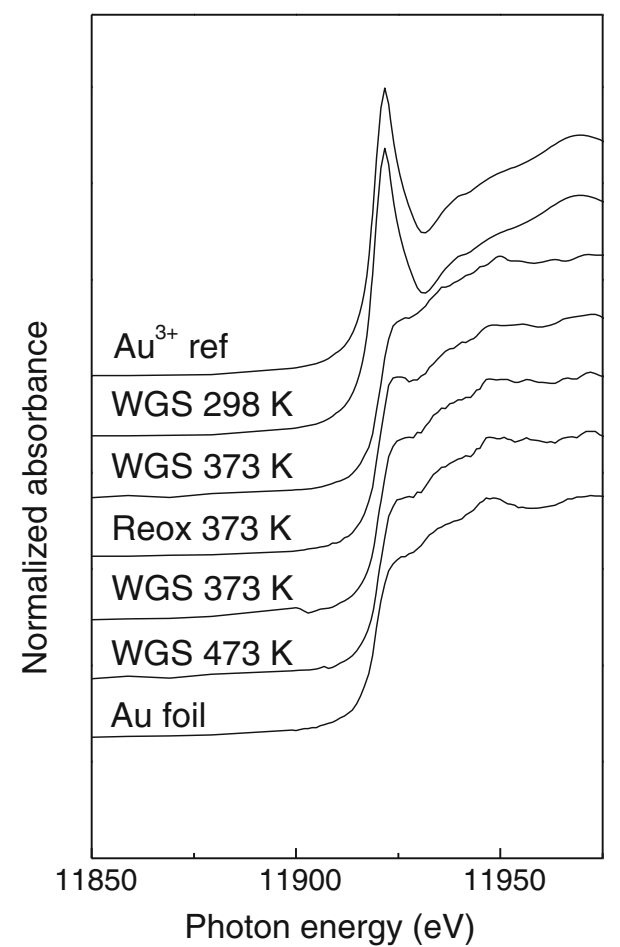

Fig. 10 Near-edge spectra at the $\mathrm{Au} \mathrm{L}_{\mathrm{III}}$ edge of $\mathrm{Au} / \mathrm{CeO}_{2}(\operatorname{rod})-\mathrm{CN}$ during the WGS reaction and upon reoxidation. Spectra of fresh $\mathrm{Au} /$ $\mathrm{CeO}_{2}$ (rod)-CN and a $\mathrm{Au}$ foil are shown for reference

intrinsic activity is even higher after cyanide leaching of $\mathrm{Au} / \mathrm{CeO}_{2}$ (rod) and amounts to $0.47 \mathrm{~s}^{-1}$. This difference is consistent with our previous results [11].

\section{General Discussion}

The results of this study further underpin the notion that the specific surface plane of ceria to which gold atoms binds has a very profound influence on the nature and catalytic activity of gold. These ceria nanorods are most likely enclosed by $\{110\}$ and $\{100\}$ surface planes [26, 30, 41]. Deposition-precipitation of gold results in a small fraction of gold atoms that interact so strongly with the ceria surface that these cannot be leached. Calcination results in the dispersion of a more substantial fraction of gold ions into the surface. EXAFS spectroscopy suggests that these $\mathrm{Au}$ cations substitute Ce ions in the surface. These dispersed cations resist cyanide leaching. The amount of gold cations that can be accommodated on the nanorods in this manner does not depend on the initial gold loading. This suggests that some specific sites at the ceria nanorod surface are able to accommodate these cations. For a polycrystalline $\mathrm{CeO}_{2}$ support with a surface area of $80 \mathrm{~m}^{2} / \mathrm{g}$ prepared by hydrolysis of $\mathrm{Ce}\left(\mathrm{NO}_{3}\right)_{3}$ with urea at $363 \mathrm{~K}$, we found that only $0.08 \mathrm{wt} \%$ Au could be retained upon cyanide leaching

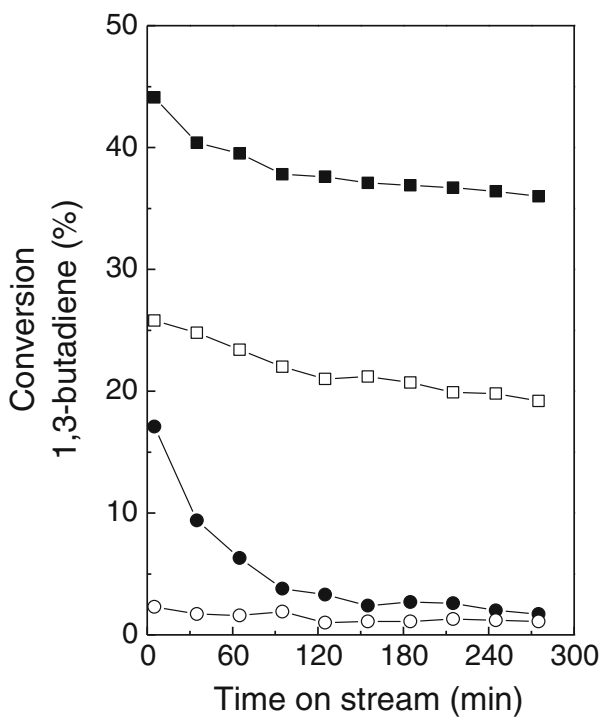

Fig. 11 Butadiene conversion during alkene hydrogenation of filled squares $\mathrm{Au} / \mathrm{CeO}_{2}$ (rod) and filled circles $\mathrm{Au} / \mathrm{CeO}_{2}$ (cube) (open markers are the cyanide-leached catalysts)

[11]. The structure around these gold cations is very similar to that determined for $\mathrm{Au} / \mathrm{CeO}_{2}$ (rod)-CN. This finding suggests that the higher amount of gold retained in the latter case is due to the higher contribution of $\{110\}$ surface planes to the surface area of $\mathrm{CeO}_{2}$ (rod) compared to that of $\mathrm{CeO}_{2}$. Others have suggested that gold cations can form a solid solution with $\mathrm{CeO}_{2}[20,33,37-40]$. Recently, Kurzman et al. have reported a thermally stable $\mathrm{Au}^{3+} \mathrm{O}_{4}$ entity within $\mathrm{La}_{4} \mathrm{LiAuO}_{8}$ [76].

Characterization shows that reduction of $\mathrm{Au} / \mathrm{CeO}_{2}$ (rod)$\mathrm{CN}$ results in very small gold clusters. The FTIR results suggest that these small clusters are present in $\mathrm{Au} /$ $\mathrm{CeO}_{2}$ (rod) and $\mathrm{Au} / \mathrm{CeO}_{2}$ (rod)-CN. The former catalyst also contains gold nanoparticles. Of importance is that these small gold clusters can be reoxidized to a large extent. In contrast, the gold nanoparticles may accommodate some oxygen atoms at their surface as follows from the changes in the position of the relevant IR band of adsorbed $\mathrm{CO}$. It appears that deposition-precipitation of gold on $\mathrm{CeO}_{2}$ (cube), which mainly exposes $\{100\}$ surface planes, only gives reduced gold nanoparticles. The behavior in CO IR spectroscopy upon reduction and oxidation is very similar to that of the nanoparticles in $\mathrm{Au} / \mathrm{CeO}_{2}$ (rod). Thus, the main difference between $\mathrm{Au} / \mathrm{CeO}_{2}$ (rod) and $\mathrm{Au} / \mathrm{CeO}_{2}$ (cube) is the presence of isolated gold cations stabilized by the $\{110\}$ in the former. These cations resist cyanide leaching and form finely dispersed gold clusters upon reduction.

The catalytic activity in $\mathrm{CO}$ oxidation has been argued to depend on the simultaneous presence of cationic and reduced gold [3]. In accordance with this, $\mathrm{Au} / \mathrm{CeO}_{2}$ (cube), which does not contain cationic gold species, has a very 
low $\mathrm{CO}$ oxidation activity. The $\mathrm{Au} / \mathrm{CeO}_{2}$ (rod) catalysts exhibit a higher activity. The intrinsic activity of the leached catalyst is higher than that of the parent one. Fresh $\mathrm{Au} / \mathrm{CeO}_{2}$ (rod)-CN is active in $\mathrm{CO}$ oxidation at $313 \mathrm{~K}$. Although this may suggest that gold cations are also active for this reaction, Gates and co-workers [63] have shown that very small gold clusters are formed from isolated gold during reaction. The increase of the activity of $\mathrm{Au} /$ $\mathrm{CeO}_{2}$ (rod)-CN upon reduction underpins the notion that reduced gold atoms are beneficial for $\mathrm{CO}$ oxidation. On the other hand, the high activity appears also to be correlated to the ability of the small gold clusters in $\mathrm{Au} / \mathrm{CeO}_{2}$ (rod)-CN to be reoxidized [77]. The observation that part of the high activity of $\mathrm{Au} / \mathrm{CeO}_{2}$ (rod) is lost may point to the loss of finely dispersed gold clusters due to agglomeration with the larger nanoparticles. For the case of the leached catalyst, these gold clusters remain dispersed and this provides a reasonable explanation for the higher intrinsic activity in $\mathrm{CO}$ oxidation after reduction.

Similarly, clear indications have been found that the presence of surface oxygen at the gold surface is important for high activity in the WGS reaction [73]. Thus, the finely dispersed gold clusters obtained from $\mathrm{Au} / \mathrm{CeO}_{2}$ (rod)-CN are more active catalysts than the gold nanoparticles in $\mathrm{Au} /$ $\mathrm{CeO}_{2}$ (rod). The higher activity of the leached catalyst is maintained up to reasonably high temperature, whereupon probably more extensive reduction to larger gold nanoparticles occurs [73] and less oxygen can be stabilized. This trend can also be observed from the CO IR data that point to a decreasing contribution of finely dispersed gold with increasing reduction temperature. The WGS reaction conditions appear to be more conducive to gold agglomeration than those involved in $\mathrm{CO}$ oxidation and 1,3-butadiene hydrogenation [11], an effect which is undoubtedly due to the presence of water. Moreover, we found that exposure of the gold cations in $\mathrm{Au} / \mathrm{CeO}_{2}$ (rod) to the WGS feed $\left(\mathrm{CO} / \mathrm{H}_{2} \mathrm{O}\right)$ at $373 \mathrm{~K}$ already results in full reduction in contrast to reduction in $\mathrm{H}_{2}$ at the same temperature. $\mathrm{Au} / \mathrm{CeO}_{2}$ (cube) does not contain cationic gold and accordingly shows a very low activity in the WGS reaction [26].

The catalytic activity of these catalysts in the selective oxidation of benzylic alcohol is related to the presence of metallic gold particles. The gold cations in $\mathrm{Au} / \mathrm{CeO}_{2}$ (rod)$\mathrm{CN}$ do not show any activity. It has been put forward that $\mathrm{C}-\mathrm{H}$ bond cleavage at the gold surface is the rate limiting step in alcohol oxidation [78, 79]. Another important step is the proton abstraction from the alcohol group. Indeed, very often a soluble base is added to facilitate this reaction [80]. The support may also act as a base [42]. In the absence of a base, $\mathrm{O}-\mathrm{H}$ bond activation may be slow and, in such case, surface oxygen atoms may facilitate this process. Interestingly, the activity of $\mathrm{Au} / \mathrm{CeO}_{2}$ (rod) is higher than that of $\mathrm{Au} / \mathrm{CeO}_{2}$ (cube) in the absence of a soluble base. A tentative explanation is the role of the $\mathrm{CeO}_{2}$ surface or of the gold cations in oxygen activation, thus facilitating alcohol activation. Indeed, both catalysts become much more active upon addition of $\mathrm{NaOH}$. Thus, without base the $\mathrm{O}-\mathrm{H}$ bond cleavage is argued to be the rate limiting step, while this shifts to $\mathrm{C}-\mathrm{H}$ bond activation in the presence of $\mathrm{NaOH}$. In the latter case, the gold nanoparticles on the surface of ceria nanocubes are much more active than those on the surface of nanorod ceria. The reason for the substantially higher activity of $\mathrm{Au} / \mathrm{CeO}_{2}$ (cube) remains unclear here.

The intrinsic activity in 1,3-butadiene hydrogenation of $\mathrm{Au} / \mathrm{CeO}_{2}$ (rod)-CN (TOF $=0.47 \mathrm{~s}^{-1}$ ) is higher than that of its unleached counterpart $\left(\mathrm{TOF}=0.21 \mathrm{~s}^{-1}\right)$. These results are in qualitative agreement with the results for a gold catalyst supported by polycrystalline $\mathrm{CeO}_{2}$ [11]. The activity difference is however substantially smaller and this is related to the relatively low reduction temperature of $393 \mathrm{~K}$ employed in this study. As follows from the nearedge spectra, a substantial part of the gold phase in $\mathrm{Au} /$ $\mathrm{CeO}_{2}$ (rod)-CN remains in the oxidic phase. The catalysts deactivate slightly with reaction time, which is due to some coke formation on the surface as is evident from the color change of the catalysts.

\section{Conclusions}

The gold phase supported on ceria nanorods and nanocubes shows a strong dependence of the catalytic activity on the exposed surface planes of ceria. After standard depositionprecipitation, both forms of ceria contain gold nanoparticles in the range $2-6 \mathrm{~nm}$, which can be removed by cyanide leaching. Additionally, the ceria nanorods stabilize a small amount of gold cations, which resist cyanide leaching. EXAFS of the leached ceria nanorod catalyst shows that the gold cations replace $\mathrm{Ce}$ ions in the surface plane of the nanorods. Upon reduction these isolated Au atoms form finely dispersed Au clusters with a high activity in $\mathrm{CO}$ oxidation, the WGS reaction and 1,3-butadiene hydrogenation. By analogy with the very low activity of reduced gold nanoparticles on ceria nanocubes exposing the $\{100\}$ surface plane, it is inferred that the gold nanoparticles on the ceria nanorod surface also have a low activity in such reactions. For liquid phase alcohol oxidation, metallic gold nanoparticles are the active sites. In the absence of a base, the $\mathrm{O}-\mathrm{H}$ bond cleavage appears to be rate limiting, while this shifts to $\mathrm{C}-\mathrm{H}$ bond activation after addition of $\mathrm{NaOH}$. In the latter case, the gold nanoparticles on the surface of ceria nanocubes are much more active than those on the surface of nanorod ceria. 
Acknowledgments This work was financially supported by the National Research School Combination Catalysis (NRSC-Catalysis) and the Program for Strategic Scientific Alliances between China and Netherlands funded by the Royal Netherlands Academy of Arts and Science and the Chinese Ministry of Science and Technology. We thank the Soft Matter Cryo-TEM Research Unit for access to the TEM facility, NWO for access to X-ray absorption spectroscopy facilities at ESRF and ESRF staff for their support.

Open Access This article is distributed under the terms of the Creative Commons Attribution Noncommercial License which permits any noncommercial use, distribution, and reproduction in any medium, provided the original author(s) and source are credited.

\section{References}

1. Bond GC, Louis C, Thompson DT (2007) Catalysis by gold. Imperial College Press, London

2. Corma A, Garcia H (2008) Chem Soc Rev 37:2096

3. Fierro-Gonzalez JC, Gates BC (2008) Chem Soc Rev 37:2127

4. Haruta M, Yamada N, Kobayashi T, Iijima S (1989) J Catal 115:301

5. Esch F, Fabris S, Zhou L, Montini T, Africh C, Fornasiero P, Comelli G, Rosei R (2005) Science 309:752

6. Campbell C, Peden C (2005) Science 309:713

7. Fierro-Gonzales JC, Gates BC (2004) J Phys Chem B 108:16999

8. Fierro-Gonzales JC, Gates BC (2007) Catal Today 122:201

9. Enache DI, Knight DW, Hutchings GJ (2005) Catal Lett 103:43

10. Azizi Y, Petit C, Pitchon V (2008) J Catal 256:338

11. Guan Y, Hensen EJM (2009) Phys Chem Chem Phys 11:9578

12. Fu Q, Saltsburg H, Flytzani-Stephanopoulos M (2003) Science 301:935

13. Kim CH, Thompson LT (2006) J Catal 244:248

14. Karpenko A, Leppelt R, Plzak V, Behm RJ (2007) J Catal 252:231

15. Claus P, Brückner A, Mohr C, Hofmeister H (2000) J Am Chem Soc 122:11430

16. Guzman J, Gates BC (2003) Angew Chem Int Ed 42:690

17. Zhang X, Shi H, Xu BQ (2005) Angew Chem Int Ed 44:7132

18. Fu Q, Weber A, Flytzani-Stephanopoulos M (2001) Catal Lett $77: 87$

19. Carrettin S, Concepcion P, Corma A, Nieto JML, Puntes VF (2004) Angew Chem Int Ed 43:2538

20. Venezia AM, Pantaleo G, Longo A, Carlo GD, Casaletto MP, Liotta FL, Deganello G (2005) J Phys Chem B 109:2821

21. Abad A, Concepcion P, Corma A, Garcia H (2005) Angew Chem Int Ed 44:4066

22. Lai SY, Qiu YF, Wang SJ (2006) J Catal 237:303

23. Tang Z, Edwards JK, Bartley JK, Taylor SH, Carley AF, Herzing AA, Kiely CJ, Hutchings GJ (2007) J Catal 249:218

24. Yuan ZY, Idakiev V, Vantomme A, Tabakova T, Ren TZ, Su BL (2008) Catal Today 131:203

25. Jia KM, Zhang HL, Li WC (2008) Chin J Catal 29:1089

26. Si R, Flytzani-Stephanopoulos M (2008) Angew Chem Int Ed 47:2884

27. Huang XS, Sun H, Wang LC, Liu YM, Fan KN, Cao Y (2009) Appl Catal B 90:224

28. Yi GQ, Xu ZN, Guo GC, Tanaka K, Yuan YZ (2009) Chem Phys Lett 479:128

29. Zhang YW, Si R, Liao CS, Yan CH, Xiao CX, Kou Y (2003) J Phys Chem B 107:10159

30. Mai HX, Sun LD, Zhang YW, Si R, Feng W, Zhang HP, Liu HC, Yan CH (2005) J Phys Chem B 109:24380
31. Lu JL, Gao HJ, Shaikhutdinov S, Freund HJ (2007) Catal Lett $114: 8$

32. Tibiletti D, Amieiro-Fonseca A, Burch R, Chen Y, Fisher J, Goguet A, Hardacre C, Hu P, Thompsett A (2005) J Phys Chem B 109:22553

33. Zhang CJ, Michaelides A, King DA, Jenkins SJ (2009) J Phys Chem C 113:6411

34. Baron M, Bondarchuk O, Stacchiola D, Shaikhutdinov S, Freund HJ (2009) J Phys Chem C 113:6042

35. Castellani NJ, Branda MA, Neyman KM, Illas F (2009) J Phys Chem C 113:4948

36. Chen Y, Hu P, Lee MH, Wang HF (2008) Surf Sci 602:1736

37. Camellone MF, Fabris S (2009) J Am Chem Soc 131:10473

38. Shapovalov V, Metiu H (2007) J Catal 245:205

39. Skoda M, Cabala M, Matolinova I, Prince KC, Skala T, Sutara F, Veltruska K, Matolin V (2009) J Chem Phys 130:034703

40. Zhang CJ, Michaelides A, King DA, Jenkins SJ (2008) J Chem Phys 129:194708

41. Zhou KB, Wang X, Sun XM, Peng Q, Li YD (2005) J Catal 229:206

42. Yang J, Guan YJ, Verhoeven T, van Santen R, Li C, Hensen EJM (2009) Green Chem 11:322

43. Liu XW, Zhou KB, Wang L, Wang BY, Li YD (2009) J Am Chem Soc 131:3140

44. Akita T, Okumura M, Tanaka K, Kohyama M, Haruta M (2005) J Mater Sci 40:3101

45. Akita T, Tanaka K, Kohyama M (2008) J Mater Sci 43:3917

46. Majimel J, Lamirand-Majimel M, Moog I, Feral-Martin C, Treguer-Delapierre M (2009) J Phys Chem C 113:9275

47. Perrichon V, Laachir A, Bergeret G, Frety R, Tournayan L, Touret O (1994) J Chem Soc Faraday Trans 90:773

48. Fu Q, Deng WL, Saltsburg H, Flytzani-Stephanopoulos M (2005) Appl Catal B Environ 56:57

49. Delannoy L, Weiher N, Tsapatsaris N, Beesley AM, Nchari L, Schroeder SLM, Louis C (2007) Top Catal 44:263

50. Corma A, Boronat M, Gonzalez S, Illas F (2007) Chem Commun 3371

51. Fujitani T, Nakamura I, Akita T, Okumura M, Haruta M (2009) Angew Chem Int Ed 48:9515

52. Kartusch C, van Bokhoven JA (2009) Gold Bull 42:343

53. Guzman J, Carrettin S, Corma A (2005) J Am Chem Soc 127:3286

54. Laachir A, Perrichon V, Badri A, Lamotte J, Catherine E, Lavalley JC, Elfallah J, Hilaire L, Lenormand F, Quemere E, Sauvion GN, Touret O (1991) J Chem Soc Faraday Trans 87:1601

55. Daly H, Ni J, Thompsett D, Meunier FC (2008) J Catal 254:238

56. Mihaylov M, Knozinger H, Hadjiivanov K, Gates BC (2007) Chem Ing Tech 79:795

57. Menegazzo F, Manzoli M, Chiorino A, Boccuzzi F, Tabakova T, Signoretto M, Pinna F, Pernicone N (2006) J Catal 237:431

58. Chiorino A, Manzoli M, Menegazzo F, Signoretto M, Vindigni F, Pinna F, Boccuzzi F (2009) J Catal 262:169

59. Vindigni F, Manzoli M, Chiorino A, Boccuzzi F (2009) Gold Bull 42:106

60. Guan Y, Hensen EJM (2009) Appl Catal A Gen 361:49

61. Aguilar-Guerrero V, Gates BC (2007) Chem Commun 3210

62. Fierro-Gonzalez JC, Guzman J, Gates BC (2007) Top Catal 44:103

63. Aguilar-Guerrero V, Gates BC (2008) J Catal 260:351

64. Hao YL, Gates BC (2009) J Catal 263:83

65. Aguilar-Guerrero V, Lobo-Lapidus RJ, Gates BC (2009) J Phys Chem C 113:3259

66. Miller JT, Kropf AJ, Zha Y, Regalbuto JR, Delannoy L, Louis C, Bus E, van Bokhoven JA (2006) J Catal 240:222

67. Jones PG, Rumpel H, Schwarzmann E, Sheldrick GM (1979) Acta Crystallogr Sect B Struct Crystallogr Cryst Chem 35:1435 
68. Wang J, Wang G, Zhao J (2002) Phys Rev B Condens Matter $66: 35418$

69. Soule de Bas B, Ford MJ, Cortie MB (2004) J Mol Struct (THEOCHEM) 686:193

70. Jain PK (2005) Struct Chem 16:421

71. Simakov A, Tuzovskaya I, Pestryakov A, Bogdanchikov N, Gurin V, Avalos M, Farias MH (2007) Appl Catal A Gen 331:121

72. Wang XY, Wang SP, Wang SR, Zhao YQ, Huang J, Zhang SM, Huang WP, Wu SH (2006) Catal Lett 112:115

73. Deng W, Frenkel AI, Si R, Flytzani-Stephanopoulos M (2008) J Phys Chem C 112:12834

74. Della Pina C, Falletta E, Prati L, Rossi M (2008) Chem Soc Rev 37:2077
75. Schimpf S, Lucas M, Mohr C, Rodemerck U, Bruckner A, Radnik J, Hofmeister H, Claus P (2002) Catal Today 72:265

76. Kurzman JA, Ouyang XY, Im WB, Li J, Hu J, Scott SL, Seshadri R (2010) Inorg Chem 49:4670

77. Bond GC (2010) Gold Bull 43:88

78. Abad A, Corma A, Garcia H (2008) Chem Eur J 14:212

79. Conte M, Miyamura H, Kobayashi S, Chechik V (2009) J Am Chem Soc 131:7189

80. Hutchings GJ, Carrettin S, Landon P, Edwards JK, Enache D, Knight DW, Xu YJ, Carley AF (2006) Top Catal 38:223 